

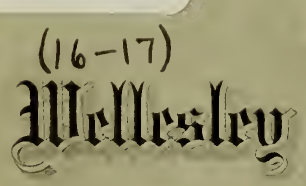

teilinaty ut

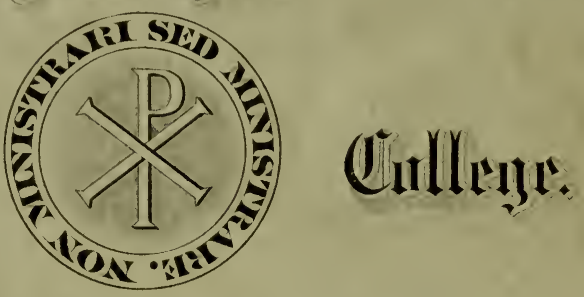

Hindiand frou

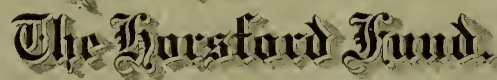

ve10 5311 




\section{Descriptions of Cuban Plants New to Science}

\section{Nathaniel Lord Britton}

The following descriptions of plants new to the Cuban Flora are drawn mostly from specimens collected in recent years on the several expeditions made under the auspices of the New York Botanical Garden and from those collected by Brother Léon of the College of La Salle, Vedado, Havana, and his associates. Brother Léon has contributed descriptions of some grasses; Dr. John H. Barnhart the Lentibulariaceae; Dr. Francis W. Pennell the Scrophulariaceae; Dr. S. F. Blake has cooperated with some Carduaceae; Dr. Rydberg has contributed a new genus of Fabaceae and Mr. Percy Wilson has assisted at many points.

\section{Family POACEAE}

Paspalum Rocanum Fr. Léon, sp. nov.

Perennial from a short rhizome; stems simple, erect or ascending, 40-60 cm. long, sometimes more; nodes appressedpubescent; sheaths glabrous, sometimes papillose-ciliate, the lower ones overlapping and often purplish; ligule membranaceous, 2.4-2.8 mm. long; blades glabrous on both surfaces, conduplicate, acuminate and involute towards apex, rarely flat, up to $25 \mathrm{~cm}$. long, $2-8 \mathrm{~mm}$. wide, firm, erect, somewhat curved; racemes 2 to 4 , somewhat divergent, straight or curved, $5-9 \mathrm{~cm}$. long, the common axis $2-4.5 \mathrm{~cm}$. long; rachis $\mathrm{I} .5-2 \mathrm{~mm}$. broad, with long hairs at base, otherwise glabrous; spikelets normally in pairs, sometimes crowded, one of the pedicels as long as or longer than the spikelet; spikelets yellowish-green, becoming rufous at maturity, glabrous, $2 . \mathrm{I}-2.5 \mathrm{~mm}$. long, I.3-r.6 mm. wide, oval to obovate; glume and sterile lemma equal, short-pointed, 3-nerved; fruit pale, minutely roughened.

Palm barren, sabana de Motembo, Santa Clara (Léon \& Roca 8233), is the type, preserved in Colegio De La Salle Herbarium. Vedado, Havana.

Sabana del Jacán, near San Miguel de los Baños, Matanzas (Léon \& Roca 887I).

Memoirs of the Torrey Botanical Club, Vol. i6, No. 2. Issued Sepber I0, 1920 . 
Paspalum Edmondi Fr. Léon, sp. nov.

A small tufted perennial with short rhizomes and numerous slender pubescent leafy branching stolons; stems simple, vcry slender, compressed, glabrous, 2-6 cm. long; leaves crowded at the base; sheaths pilose; ligule membranaceous, 0.5-I mm. long; blades lanceolate to linear, pilose on the upper surface towards the base and near the lower margins, glabrous beneath, I-I.5 cm. long, sometimes up to $6 \mathrm{~cm}$. long in the specimens grown in a rich soil, I-2 $\mathrm{mm}$. wide, flat or somewhat involute towards apex; racemes solitary, up to $\mathrm{I} 2 \mathrm{~mm}$. long, usually about $6 \mathrm{~mm}$., with a tuft of hairs at the base; rachis $0.5-0.7 \mathrm{~mm}$. wide, glabrous; pedicels shorter than the spikelets; spikelets solitary, with a short wing along the pedicel, somewhat imbricate, I.5-2 mm. long, I-I.2 $\mathrm{mm}$. wide, ovate, abruptly acuminate-pointed; first glume wanting, second glume glabrous, often transversely wrinkled, 7nerved, conspicuously pointed; sterile lemma glabrous, more or less deeply hollowed between the strongly elevated, rugose, sometimes tubercled margins, nearly as long-pointed as the second glume; fruit blunt, brown, slightly papillose, I.4 mm. long, I $\mathrm{mm}$. wide.

Palm barren, sabana de Motembo, Santa Clara (Léon \& Edmond 8607).

Specimens from the same locality were transplanted in Vedado, Havana (Léon \& Edmond 8682). The type specimens are preserved in the Colegio De La Salle Herbarium, Vedado, Havana.

Paspalum acutifolium Fr. Léon, sp. nov.

Perennial, tufted; culms simple, erect or ascending, glabrous, compressed, nearly naked, much exceeding the leaves, these densely crowded at the base; nodes clothed with long white hairs; sheaths striate, keeled, mostly overlapping, glabrous, sometimes sparsely hispid towards the summit, hirsute-ciliate, the upper ones bladeless or nearly so; ligule membranaceous up to $2 \mathrm{~mm}$. long ; blades firm, rarely over I $5 \mathrm{~cm}$. long, $4-8 \mathrm{~mm}$. wide, sparsely papillose-hispid on both surfaces and the margin when young, mostly flat or conduplicate, sometimes twisted, involute towards apex, the middle nerve prominent beneath; inflorescence terminal; racemes 2 to 4 , the common axis $\mathrm{I}-3.5 \mathrm{~cm}$. long, with long white hairs at base ; racemes straight or slightly curved, divergent, rarely spreading; rachis about I mm. wide, bearing a few long hairs at the base, otherwise glabrous; spikelets normally in . 
pairs, crowded towards the summit, only one developed in the lower pairs, the other rudimentary or wanting; spikelets about twice as long as the pedicel, elliptic, r.6-1.8 mm. long, I mm. wide, more or less crimson; second glume and sterile lemma subequal, with some spreading hairs near the margin, otherwise glabrous; fruit pale, somewhat exceeding the second glume at maturity; palea somewhat papillose-roughened.

Palm barren, sabana de Motembo, Santa Clara (Léon \& Roca 8164). The type specimen is preserved in the Colegio De La Salle Herbarium, Vedado, Havana.

\section{Family CYPERACEAE}

Cyperus camagueyensis Britton, sp. nov.

Perennial; culms tufted, slender, smooth, trigonous, erect, 3-6 dm. high. Basal leaves much shorter than the culm, I-I.5 $\mathrm{dm}$, long, $3 \mathrm{~mm}$. wide or less, those of the involucre several, the longer ones much surpassing the simple, several-rayed umbel; umbel-rays very slender, $5 \mathrm{~cm}$. long or less; spikelets loosely spicate, I.5-3 cm. long, flat, many-flowered, the rachis angular, wingless, persistent after the scales have fallen; scales oblonglanceolate, brown, appressed, acute, $1.5 \mathrm{~mm}$. long; stamens 2 or 3 ; style-branches 2, filiform ; achenes oblong, grey, smooth, apiculate, $0.75 \mathrm{~mm}$. long, nearly $0.5 \mathrm{~mm}$. thick, persistent.

Vicinity of La Gloria, Camaguey (Shafer 196).

Cyperus Underwoodii Britton, sp. nov.

Culms densely tufted, slender but rigid, erect, arching or recurved, I-4 dm. long. Basal leaves $\mathrm{I}-5 \mathrm{~cm}$. long, or reduced to sheaths, those of the involucre $\mathrm{I}-3$, the longest about $7 \mathrm{~cm}$. long or shorter, sometimes only I cm. long or less; spikelets few or several in a dense terminal cluster, nearly terete, 5-10 mm. long, few-flowered; scales brown, striate, oval, obtusish, appressed, about $2 \mathrm{~mm}$. long; achene linear-oblong, trigonous, apiculate, 2 $\mathrm{mm}$. long, about $0.5 \mathrm{~mm}$. thick.

Dry soil, vicinity of Santiago, Oriente (Underwood 169f).

Eleocharis Shaferi Britton, sp. nov.

Perennial; culms capillary, weak, densely tufted, about 2 $\mathrm{dm}$. long; upper sheath apparently not scarious; spikelet oblong, 4-5 mm. long, I-I.5 mm. thick, acute, few-flowered; scales pale, appressed, obtuse or obtusish, oblong or oblong-lanceolate, appressed, the lower one $2-2.5 \mathrm{~mm}$. long, shorter than the upper 
ones; bristles 4-6, brownish, about as long as the achene and tubercle; style-branches 2 ; achene black, lenticular, oblong, I mm. long; tubercle sharply conic, one-fourth as long as the achene.

Bog-holes in wet thicket, Sierra Nipe near Woodfred, Oriente (Shafer 34I4).

Eleocharis minutissima Britton, sp. nov.

Culms capillary, weak, densely tufted and matted, only I.5-3 $\mathrm{cm}$. high. Spikelets ovoid, 2-4-flowered, acute, I mm. long; scales ovate, acute, with a narrow dark brown central band and broad hyaline margins; achene $0.25 \mathrm{~mm}$. long, cancellate and longitudinally ribbed, gray, oblong-ovoid; tubercle black, lowconic ; bristles none.

Border of a lagoon near Pinar del Rio (Britton \& Gager $6965)$.

Fimbristylis ophiticola Britton, sp. nov.

Perennial; culms tufted, glabrous, $5 \mathrm{~cm}$. high or higher. Leaves mostly basal, shorter than the culm; spikelet solitary (or sometimes 2 ?), ovate, flat, several-flowered, acutish, 6-12 $\mathrm{mm}$. long, 2-4 $\mathrm{mm}$. wide; scales ovate, somewhat spreading, yellowbrown, shining, acute or acutish, faintly nerved, readily deciduous from the deeply pitted rachis; style-branches 2 ; style compressed pubescent. deciduous; achene obovate, nearly white, 0.5 $\mathrm{mm}$. long, flat, longitudinally striate and transversely barred.

Serpentine palm-barren, between Camaguey and Santayana, Camaguey (Britton 2429, type); a plant from the vicinity of Guanabacoa, Havana (Father Roca No. I), much larger than the type specimen but without achenes, may belong here.

\section{Family AMARYLLIDACEAE}

Hymenocallis praticola Britton \& Wilson, sp. nov.

Leaves linear-lanceolate, $3-3.8 \mathrm{dm}$. long, $1.5-2.8 \mathrm{~cm}$. broad, acute at the apex, gradually narrowing below, sessile. Scape slender, $2-3 \mathrm{dm}$. tall; flowers 6 or 7 in an umbel, sessile; outer spathe-valves deltoid-lanceolate, $3.5-4.5 \mathrm{~cm}$. long; perianth-tube slender, 7-II cm. long, the lobes linear, 6.5-9 cm. long, shorter than the tube; staminal crown funnel-shaped, $2-2.5 \mathrm{~cm}$. high, toothed on the edge between the free tips of the filaments, which are 3-4 cm. long; anthers linear, I.2-I.5 cm. long; style slender, longer than the anthers.

Wet savanna, Sagua, Santa Clara (Britton \& Wilson 370, type); also collected at Cieneguita, Santa Clara (Combs 345). 


\section{Family ORCHIDACEAE}

Vanilla savannarum Britton, sp. nov.

Climbing on palms; stem slender, branched, $6 \mathrm{~m}$. long or longer. Leaves ovate to ovate-lanceolate, 6-ro $\mathrm{cm}$. long, 3-5 $\mathrm{cm}$. wide, bluntly acute or obtuse at the apex, rounded at the base, many-veined, the petioles about $5 \mathrm{~mm}$. long; peduncles short, 4-8 cm. long, leafy-bracted; spike $6 \mathrm{~cm}$. long or less, densely several-many-flowered; capsules sub-cylindric, sessile, 4-5 cm. long.

On Copernicia, savannas near Camaguey (Britton \& Cowell I3I2O, type) ; on Copernicia, barren savannas southeast of Holguin, Oriente (Shafer 2944); on Copernicia, savanna south of Sierra Cubitas, Camaguey (Shafer $I 83 I$ ) ; on palmetto, between La Gloria and Columbia, Camaguey (Shafer 615); on palmetto, Jatovieja, Cayo Sabinal, Camaguey (Shafer 1072).

\section{Family PIPERACEAE}

Peperomia similis Britton, sp. nov.

Stem rather slender, creeping, sparingly branched, $4 \mathrm{dm}$. long or longer, about $2 \mathrm{~mm}$. thick, sparingly pubescent in lines of curled hairs. Leaves alternate, firm in texture, orbicular-ovate, $3 \mathrm{~cm}$. long or less, glabrous or nearly so, copiously black-dotted, obtuse or acutish at the apex, rounded or subtruncate at the base, inconspicuously 5 -nerved, the rather stout petioles $3-8 \mathrm{~mm}$. long; young spikes terminal, solitary, short-peduncled, about 8 $\mathrm{cm}$. long and $2 \mathrm{~mm}$. thick, the bracts rounded.

On a rock, bank of arroyo, Sierra del Indio, San Diego de los Baños, Pinar del Rio (Brothers Léon and Charles 4984).

Peperomia cueroensis Britton, sp. nov.

Peperomia spathophylla monteverdensis C. DC. in Urban, Symb. Ant. 3: 228. 1902.

Stems stout, branched, $3 \mathrm{dm}$. long or less. Leaves thick and firm, elliptic to ovate or obovate, $3-7 \mathrm{~cm}$. long, obtuse or some of them acute at the apex, narrowed or obtuse at the base, faintly 3-nerved, loosely pubescent when young, soon glabrous, not black-punctate; spikes solitary, very long, terminal, about $25 \mathrm{~cm}$. long, 2-2.5 $\mathrm{mm}$. thick; bracts oval, distant.

Mountains of Oriente; type collected on rocks in a ravine, $420 \mathrm{~m}$. altitude, near El Cuero, Oriente (Britton \& Cor'ell $1276 I)$. 
As grown at The New York Botanical Garden, the young leaves are always pubescent, but become glabrous soon after reaching their full size.

\section{Family URTICACEAE}

Pilea sumideroensis Britton, sp. nov.

Fleshy, bushy, glabrous, branched, 2.5-4 dm. high, the branches stout, ascending, the main stem nearly I cm. thick. Leaves thick, fleshy, obovate, 6-r $8 \mathrm{~mm}$. long, entire, obscurely pinnately about 5 -veined, rounded at the apex, cuneate at the base, the margins revolute, the upper surface densely covered with linear raphides, the under surface finely reticulate when dry, the very slender petiole $9 \mathrm{~mm}$. long or less.

Top of high cliff, limestone hills, vicinity of Sumidero, Pinar del Rio (Shafer I38I6). Described from sterile specimens, but apparently not referable to any previously known species.

Pilea (?) carnosa Britton, sp. nov.

Shrubby, erect, fleshy, $5 \mathrm{dm}$. high, the stems white. Leaves thick, nearly orbicular, 6-12 mm. broad, faintly 3-nerved, rounded at the apex, rather abruptly narrowed at base into slender petioles $8 \mathrm{~mm}$. long or less.

Cliff, at $160 \mathrm{~m}$. altitude, Ensenada de Mora, Oriente (Britton, Cowell \& Shafer I2967).

A curious plant, referred to this genus with hesitation.

Pilea sevillensis Britton, sp. nov.

A slender vine, $3 \mathrm{dm}$. long or longer, creeping on the bark of trees, somewhat branched, the young twigs and petioles sparingly pubescent. Leaves oval or suborbicular, $1.5 \mathrm{~cm}$. long or less, those of each pair nearly of the same size, 3-nerved, entire, rounded at the apex, obtuse at the base, the linear raphides inconspicuous.above, prominent and loosely scattered beneath, the slender petioles $5^{-12} \mathrm{~mm}$. long; stipules semi-orbicular, 2-3 $\mathrm{mm}$. broad; cymes few-flowered, shorter than the leaves; achene about I.5 mm. long.

Cañon, Upper Guama River, Sevilla Estate, near Santiago, Oriente (Taylor I83). 
Pilea trinitensis Britton, sp. nov.

Decumbent, glabrous or minutely puberulent, branched, about $7 \mathrm{dm}$. long. Leaf-pairs, unequal; petioles slender, those of the larger leaves $2-4 \mathrm{~cm}$. long; leaf-blades oblong-lanceolate, $7 \mathrm{~cm}$. long or less, 3-nerved, entire, ciliate, acuminate at the apex, acute or obtuse at the base, rather thin in texture, the underside densely covered with minute linear raphides, the upper surface minutely papillose; staminate inflorescence glomerate-paniculate, nearly as long as the upper leaves; pistillate flowers paniculate, the panicles much shorter than the leaves.

On rocks, Los Cocos, near Siguanea, Trinidad Mountains, Santa Clara, 430 meters altitude (Britton \& Wilson 5075).

Pilea neglecta Britton, sp. nov.

Stem slender, densely covered with linear raphides. Leaves oblong to oblong-lanceolate, membranous, acute, entire, 3-veined, glabrous, the pairs unequal in size and unequally petioled; larger leaves $5 \mathrm{~cm}$. long, I. $5 \mathrm{~cm}$. wide, with petioles I cm. long; smaller leaves $2.5 \mathrm{~cm}$. long, I-I.2 cm. wide, with petioles $3 \mathrm{~mm}$. long; raphides of upper leaf-surfaces linear-filiform, very numerous and approximate, those of under leaf-surfaces thicker, bright white, numerous, but not close together ; peduncles filiform, about as long as the longer petioles; inflorescence paniculate, much shorter than the leaves, the flowers sessile in small clusters; achene oval, apiculate, scarcely $0.5 \mathrm{~mm}$. long.

Cuba, C. Wright 2233, in part, in herbarium of the Missouri Botanical Garden.

Pilea siguaneana Britton, sp. nov.

Stems stout, decumbent, 3-5 dm. long, glabrous. Leaf-pairs equal or nearly so; leaves lanceolate or oblong-lanceolate, entire. 3-nerved, 6-10 cm. long, 2-4 cm. wide, long-acuminate at the apex, obtuse or rounded at the base, the upper side covered with minute linear raphides, the underside bearing oblong, thick, white raphides, scattered or somewhat clustered; petioles $\mathrm{I}-2 \mathrm{~cm}$. long ; staminate flowers densely capitate in globose heads about $6 \mathrm{~mm}$. in diameter, on slender axillary peduncles $\mathrm{I}-2 \mathrm{~cm}$. long.

Bed of stream, Siguanea, Trinidad Mountains, Santa Clara, 400 meters altitude (Britton \& Wilson 4979).

Pilea Clementis Britton, sp. nov.

Woody; stems ascending or straggling, simple or branched. 3-4 dm. long. Leaf-pairs nearly equal, but their petioles unequal 
in length; blades ovate-lanceolate, entire, 4-6 cm. long, $2 \mathrm{~cm}$. wide or less, acuminate at the apex, rounded or obtuse at the base, strongly 3-veined with a very slender vein on each side near the margin; staminate flowers subcapitate at the ends of filiform peduncles which are mostly as long as the petioles or longer, the heads about $6 \mathrm{~mm}$. in diameter; pistillate flowers in small panicles on peduncles much shorter than the petioles; achene compressed, ovate, acute, pale, about $0.5 \mathrm{~mm}$. long.

River-banks, Banao Mountains, Santa Clara (Brothers Léon and Clement 4055, type; 5342).

Pilea bullata Britton, sp. nov.

Erect-decumbent, with rather stout, pilose-pubescent stems I-2.5 dm. long. Leaves ovate, $4 \mathrm{~cm}$. long or less, coarsely crenate, obtuse or bluntly acute at the apex, obtuse or rounded at the base, glabrous and with very numerous, approximate, minute, linear raphides above, pilose-pubescent on the prominent veins beneath, the unequal pilose petioles $2 \mathrm{~cm}$. long or less; stipules ovate, about $3 \mathrm{~mm}$. long; inflorescence glomerate-paniculate, as long as the leaves or shorter; achene ovate, acute, about $0.5 \mathrm{~mm}$. long.

Damp woods among stones, between Bahia Honda and El Rosario, Pinar del Rio (Shafer I20I8).

\section{Family PORTULACACEAE}

Portulaca cubensis Britton \& Wilson, sp. nov.

Perennial, 2-7 cm. high. Leaves oblong to elliptic, 3-4.5 $\mathrm{mm}$. long, I-2 $\mathrm{mm}$. broad, rounded at the apex, acutish at the base, fleshy, the axils sparingly short-pilose; flowers mostly solitary; corolla yellow; sepals ovate-lanceolate, 5-5.5 $\mathrm{mm}$. long, 3 $\mathrm{mm}$. broad at the base; petals obovate, 8-10 $\mathrm{mm}$. long, 2-3.5 $\mathrm{mm}$. broad, rounded at the apex, cuneate at the base; capsule circumsessile at about the middle; seeds blackish.

Type collected in palm-barrens, Motembo, Santa Clara (Léon \& Roca 84I9).

\section{Family MENISPERMACEAE}

Hyperbaena acutifola Britton, sp. nov.

A small tree with slender gray twigs. Leaves oblong-elliptic, coriaceous, 4-9 cm. long, 2-4 cm. wide, finely reticulate-veined on both sides with the midvein rather prominent, sharply acute at 
the apex, narrowed at the base, the petiole $8-16 \mathrm{~mm}$. long; inflorescence lateral, shorter than the leaves, pubescent; fruit compressed subglobose, black, about $12 \mathrm{~mm}$. in diameter and $8 \mathrm{~mm}$. thick.

Dry soil between Banao and Rincon, Santa Clara (Shafer I2I77).

Hyperbaena littoralis Britton, sp. nov.

A tree 5-8 m. high, or shrubby, the twigs slender. Leaves oval to suborbicular, coriaceous, shining, $3.5-8 \mathrm{~cm}$. long, $3-5 \mathrm{~cm}$. wide, finely reticulate-veined on both sides, with the midvein rather prominent, rounded, mucronate or rarely acute at the apex, obtuse or somewhat narrowed at the base, the petiole 5-10 $\mathrm{mm}$. long; inflorescence lateral, pubescent, shorter than the leaves; flowers sessile, green, about $2 \mathrm{~mm}$. broad; fruit black, much compressed, about I $\mathrm{cm}$. in diameter.

Coastal woods, hills and thickets, Oriente, Camaguey, Santa Clara. Type from Guajimica, Santa Clara (Britton, Earle \& Wilson 599I).

\section{Family ANNONACEAE}

Xylopia Roigii P. Wilson, sp. nov.

A shrub or small tree, the young twigs brown, strigillose with short, appressed hairs; leaves oblong-elliptic or obovate, 3.5-7 $\mathrm{cm}$. long, I-2.4 $\mathrm{cm}$. broad, rounded or somewhat acutish at the apex, cuneate at the base, glabrous and somewhat lustrous above, dull and minutely strigillose beneath with short, appressed hairs, short-petioled; flowers immature; calyx about $4 \mathrm{~mm}$. broad, the lobes triangular; outer petals oblong, 9-I I mm. long, 2.5-3 $\mathrm{mm}$. broad, densely sericeous on the back, the inner petals narrower; carpels (mature?) ellipsoid, about $2.5 \mathrm{~cm}$. long, $1.4 \mathrm{~cm}$. broad, glabrous.

Thickets, Baracoa, Oriente (Roig 99).

\section{Family LAURACEAE}

Persea Shaferi P. Wilson, sp. nov.

A slender shrub $2 \mathrm{~m}$. high, with puberulent twigs. Leaves oblong-elliptic or oblong-obovate, $4.5-7.5 \mathrm{~cm}$. long, I.5-2.5 cm. broad, acutish or obtuse at the apex, acute at the base, glabrous above, the midvein impressed, the lateral veins puberulent and rather indistinctly reticulate-veined beneath; inflorescence $S \mathrm{~cm}$. 
long, the branches puberulent; fruit (immature) subglobose, 9 $\mathrm{mm}$. in diameter.

Type collected at Camp La Gloria, south of Sierra Moa, Oriente (Shafer 8248).

\section{Family CAESALPINIACEAE}

Cassia benitoensis Britton \& Wilson, sp. nov.

Shrub I-3 m. tall; young twigs, petioles and rachis pubescent with short, stiff, incurved hairs. Leaves $5-9 \mathrm{~cm}$. long, glandular, the gland slender, $2 \mathrm{~mm}$. high, situated between the leaflets of the lowest pair; petioles and rachis narrowly grooved; stipules lanceolate, $6-7 \mathrm{~mm}$. long, acuminate; leaflets 5-6 pairs, oblongelliptic or elliptic, I.5-2.4 cm. long, I-I.2 cm. broad, rounded and mucronulate at the apex, rounded and inequilateral at the base, the margins ciliate; pods flat, $14 \mathrm{~cm}$. long, $8 \mathrm{~mm}$. broad.

Along rocky stream, vicinity of Camp San Benito, Oriente (Shafer 4072).

Caesalpinia subglauca Britton, sp. nov.

An unarmed shrub, $2.5 \mathrm{~m}$. high, the twigs glabrous. Leaves bipinnate; petiole rather stout, I-I.5 cm. long; pinnae 5 or 7 , the lower opposite or alternate, 5-10 $\mathrm{cm}$. long, the rachis loosely pubescent; leaflets 9-I5, sessile, coriaceous, glabrous, oblongovate to ovate-orbicular, I-2.5 cm. long, $7-\mathrm{I} 5 \mathrm{~mm}$. wide, strongly reticulate-veined above, pale and subglaucous beneath, the apex rounded or emarginate, the base rounded or subcordate, oblique; fruiting pedicels stout, about $2 \mathrm{~cm}$. long; pods flat, thin, puberulent, obliquely oblong, dehiscent, $3-5 \mathrm{~cm}$. long, about $1.5 \mathrm{~cm}$. wide, sharply beaked.

Hillside thicket, near Santiago, Oriente (Britton \& Cowell I2596).

Caesalpinia myabensis Britton, sp. nov.

A shrub about I.3 m. high, with slender gray branches, the young twigs densely short-pubescent. Leaves bipinnate, the petiole and rachis densely short-pubescent; petiole I-I.5 cm. long ; pinnae $5-7$, opposite, $3-5 \mathrm{~cm}$. long; leaflets $7-17$, sessile, coriaceous, loosely pubescent, dark-green and shining above, pale, dull and pubescent on the midvein beneath, strongly pinnately veined, 6-I2 mm. long; inflorescence racemose; fruiting pedicels erect, slender, pubescent, $2-2.5 \mathrm{~cm}$. long ; pods obliquely oblong, spreading, about $3 \mathrm{~cm}$. long, I-I.3 cm. wide, subulate-tipped, puberulent. 
Dry hill, between Holguin and Myabe, Oriente (Shafer I403).

Caesalpinia Hornei Britton, sp. nov.

A shrub with unarmed branches; the twigs, petioles and rachis pubescent with short incurved hairs. Leaves bipinnate; petioles rather slender, I.5-I.7 cm. long; pinnae 5-7, opposite, 5.5-7.5 cm. long; leaflets 7-II, broadly oblong to somewhat oblong-ovate, $1.5-2.5 \mathrm{~cm}$. long, and $0.9-1.5 \mathrm{~cm}$. broad, rounded and emarginate at the apex, truncate and more or less inequilateral at the base, sessile, reticulate-veined on both surfaces, glabrous and somewhat lustrous above, paler and dull beneath; inflorescence racemose; flowering pedicels erect, slender, loosely pubescent, about $2 \mathrm{~cm}$. long; corolla yellow, $2-2.4 \mathrm{~cm}$. broad; petals obovate, I-I. $2 \mathrm{~cm}$. long, 8-Io $\mathrm{mm}$. broad.

\section{Savanna, Ciego de Avila, Camaguey (Horne 95).}

\section{Family FABACEAE}

Harpalyce macrocarpa Britton \& Wilson, sp. nov.

A tree $4 \mathrm{~m}$. high, or more, with slender, spreading branches, the twigs, petioles and rachis densely puberulent with ferruginous hairs. Leaves odd-pinnate, Io- $14 \mathrm{~cm}$. long, the petioles $\mathrm{I}-2 \mathrm{~cm}$. long; leaflets II-I 5, oblong to oblong-elliptic, $2.2-3.8 \mathrm{~cm}$. long, $\mathrm{I}-\mathrm{I} .5 \mathrm{~cm}$. broad, rounded and emarginate at the apex, rounded and often subcordate at the base, short-petioled, coriaceous, glabrous and rather dull above, the veins slender and rather indistinct, finely reticulate-veined and glandular beneath, glabrous with the exception of the midvein; legume spatulate-oblanceolate. 5-6 cm. long, $1.5 \mathrm{~cm}$. broad near the apex, more or less curved, glabrous.

Border of arroyo, palm barren, Santa Clara (Britton \& Cowell I3284).

Harpalyce villosa Britton \& Wilson, sp. nov.

A tree 3-4 m. high, with rather stout grayish branches, the twigs, petioles, rachis and under surface of the leaflets densely short-villous with ferruginous hairs when young. Leaves 6-7.5 $\mathrm{cm}$. long, the petioles about $\mathrm{I} .5 \mathrm{~cm}$. long ; leaflets oblong or ellipticoblong, $2-2.7 \mathrm{~cm}$. long, 0.6-1.2 cm. broad, rounded and emarginate at the apex, rounded at the base, short-petioluled, thickcoriaceous, dark-green, glabrous and shining above, paler. indistinctly veined and conspicuously impressed glandular beneath, 
glabrescent in age with the exception of the midvein; legume oblong, $4 \mathrm{~cm}$. long, I-I.2 cm. broad, pointed at both ends; seeds ovate, $5 \mathrm{~mm}$. long, $4-4.5 \mathrm{~mm}$. broad.

Among rocks along stream, vicinity of Camp San Benito, Oriente (Shafer 4089); also collected at Moa, Baracoa (Roig $43)$.

BEMBICIDIUM Rydberg, gen. nov.

A low unarmed shrub. Leaves abruptly pinnate; stipules lanceolate, persistent; petiole and rachis broadly winged, the wings discontinuous, the rachis slightly produced above the uppermost leaflets; leaflets entire, coriaceous without veins, the midrib prominent beneath, obsolete above; stipels obsolete. Flowers solitary in the axils. Calyx turbinate, as broad as long, with two broad, subequal, acute lips; corolla purplish, with subequal petals. Banner obovate, slightly retuse, gradually tapering into the short broad claw. Wings and keel-petals equal in length and shape, the blades obliquely oblanceolate, rounded at the apex, slightly auricled at the base; claws short, straight, the blades of the keel-petals united at the middle only. Ovary slightly stipitate, linear, many-ovuled; style glabrous, bent inward at the base, slightly arcuate, not hooked at the apex; stigma minute, terminal. Fruit unknown. [Name Greek, a little top, from the small top-shaped flower buds.] A monotypic genus.

Bembicidium cubense Rydberg, sp. nov.

A shrub 5-6 dm. tall, the branches and twigs clothed with appressed, ferruginous hairs. Leaves equally pinnate, $0.7-2 \mathrm{~cm}$. long, short-petioled, glabrous, the rachis prominently winged; leaflets $2-6$, oblong to elliptic or somewhat obovate, rounded at the apex, often somewhat inequilaterally rounded at the base, sessile, dark-green, wrinkled and veinless above, brownish beneath, the midvein rather prominent, the lateral veins indistinct; margin revolute; corolla $\mathrm{I}-3 \mathrm{~cm}$. long; blade of the standard obovate; wings oblanceolate; keel-petals obanceolate, I cm. long.

Mountain woods, vicinity of Baracoa, Oriente (Shafer 4284).

Notodon cayensis Britton \& Wilson, sp. nov.

A shrub I-2 m. tall, with grayish-brown, puberulent branches, the young twigs pubescent with appressed, ferruginous hairs. Leaves equally pinnate, I-I.5 cm. long, short-petioled, glabrous, the rachis narrowly winged; leaflets 2 or 4 , obovate, 6 -I I $\mathrm{mm}$. long, 2-4 $\mathrm{mm}$. broad above the middle, rounded at the apex, 
cuneate at the base, sessile, green and with few inconspicuous veins or veinless above, whitish and veinless beneath, the margin strongly revolute; peduncles axillary, 4-5 $\mathrm{mm}$. long, slender; calyx glabrous, broadly campanulate, 4 - or 5 -toothed; corolla "bluish"; blade of the standard rounded, obovate, retuse at the apex, $5 \mathrm{~mm}$. broad; wings oblanceolate, with a small basal lobe; keel-petals oblanceolate, I cm. long; pod unknown.

Cayo Guajaba, Camaguey (Shafer 658 and 2823).

Notodon savannarum Britton \& Wilson, sp. nov.

A shrub $0.5-2.5 \mathrm{~m}$. high, the branches stiff, the young shoots finely pubescent. Stipules minute; leaves $1.5 \mathrm{~cm}$. long or less, evenly pinnate, short-petioled, glabrous, the rachis winged between the 2-4 pairs of opposite, sessile leaflets and terminating in a short tip; leaflets coriaceous, obovate or oblong-obovate, 4- 8 $\mathrm{mm}$. long, rounded at the apex, obtuse at the base, dark green and veinless above, nearly white and rather strongly pinnately fewveined beneath; stipels none; peduncles axillary, solitary, slender, glabrous, 5-8 mm. long; calyx glabrous, broadly campanulate, subtruncate and minutely 5 -toothed, about $2 \mathrm{~mm}$. long; corolla rose-purple, about I cm. long; pods (immature) $2.5-4 \mathrm{~cm}$. long, 3-4 mm. broad.

Rocky soil, savannas near Camaguey (Britton \& Corell I3I49.)

\section{CAÑIZARESIA Britton, gen. nov.}

A shrub, with alternate, short-petioled, unevenly pinnate leaves, the small opposite leaflets coriaceous, the stipules obsolete, the flowers in short axillary racemes, the bracts early deciduous, the pedicels short. Calyx subcampanulate, its teeth short, obtuse. nearly equal, the two upper ones partly united. Standard broadly ovate, rounded at the apex, subtruncate at the base, shortclawed, unappendaged; wings oblong, long-clawed; keel longclawed, arcuate, about as long as the wings, 2-lobed at the base. Stamens Io (9 and I) ; filaments filiform; anthers ovate, versatile. Ovary narrowly subcylindric, sessile, puberulent; style nearly as long as the ovary, curved near the base; stigma small, sub-capitate. Legume short-stipitate, indehiscent, linear, with four narrow subcoriaceous wings, more or less constricted between the nearly sessile ovate seeds. [In honor of Professor Felipe Garcia Cañizares.] A monotypic genus.

Canizaresia cubensis (Urban) Britton, comb. nov.

Piscidia cubensis Urban, Symb. Ant. 7 : 229. I912. 
Barren rocky savannas, Oriente, Camaguey, Santa Clara. Endemic.

\section{Bradburya lobata Britton \& Wilson, sp. nov.}

Stems twining, glabrous or sparingly pubescent with rather long, whitish hairs. Leaflets 3 , hastate-ovate with rounded lobes, 4-9.5 cm. long, 2-9 cm. broad, abruptly short-acuminate or acute at the apex, subtruncate or somewhat rounded at the base, shortpetioled, glabrous or sparingly pubescent on the veins; peduncles few-flowered; bracts lanceolate or lanceolate-ovate, several times longer than the calyx, acuminate at the apex; calyx puberulent, the lobes short; corolla purple; standard orbicular, $3.5 \mathrm{~cm}$. high, $4.5 \mathrm{~cm}$. wide, pilose on the back with appressed, ferruginous hairs; pods linear, I2-I $5 \mathrm{~cm}$. long, $8 \mathrm{~mm}$. wide; seeds $4-4.5 \mathrm{~mm}$. long, $3 \mathrm{~mm}$. wide, black.

Waste places, Vedado, Havana (Léon \& de Cubas 8507).

Erythrina venosa Britton \& Wilson, sp. nov.

A small tree, $6 \mathrm{~m}$. high, with grayish or yellowish-gray glabrous twigs, which are often closely armed with rather stout, straight prickles $2-7 \mathrm{~mm}$. long. Leaves 5 -IO $\mathrm{cm}$. long, the petioles slender, puberulent, $3-5 \mathrm{~cm}$. long; leaflets 3 , ovate to broadly ovate, $2-4.5 \mathrm{~cm}$. long, I.5-3.5 cm. broad, obtuse or occasionally rounded at the apex, often obliquely rounded at the base, glabrous and finely reticulate-veined above, coarsely reticulatevined beneath, the veins loosely pilose; short-petioluled; flowers immature; calyx broadly campanulate, puberulent; standard oval, $2 \mathrm{~cm}$. long, I. $2 \mathrm{~cm}$. broad, dark red; keel-petals obovate or obliquely obovate, $6-7 \mathrm{~mm}$. long, $2.5-3 \mathrm{~mm}$. broad, free, the wings obovate or obliquely obovate.

La Perla, Oriente (Shafer 8540).

Phaseolus savannarum Britton \& Wilson, sp. nov.

Stems pubescent with more or less reflexed hairs, erect or ascending from a perennial rootstock, the peduncles elongate, much exceeding the leaves. Leaflets oblong-linear to oblongovate, I-4 cm. long, $0.3-\mathrm{I} \mathrm{cm}$. broad, acute or occasionally rounded at the apex, rounded at the base, papillose and more or less densely pubescent above with mostly appressed hairs, appressed-pubescent beneath, coriaceous, the margin ciliate; racemes simple; flowers short-pedicelled; calyx campanulate, 2-3 $\mathrm{cm}$. long, appressed-puberulent, the lobes triangular to triangular- 
ovate ; corolla pink; wings $2-2.5 \mathrm{~cm}$. long, the standard I-I.5 cm. broad; legume linear, 4-6 cm. long, $3 \mathrm{~mm}$. broad, appressedpuberulent; seeds $2.5 \mathrm{~mm}$. long, $\mathrm{I} .5 \mathrm{~mm}$. broad.

Savannas, pine lands and palm barrens, Camaguey, Santa Clara, Matanzas, Pinar del Rio and Isle of Pines. Type from Herradura, Pinar del Rio (Earle 632).

\section{Family ERYTHROXYLACEAE}

Erythroxylon Roigii Britton \& Wilson, sp. nov.

A glabrous shrub, 2-2.5 m. high, with slender twigs. Leaves elliptic, 5-7 cm. long, $2-3.5 \mathrm{~cm}$. wide, obtuse and short-apiculate at the apex, acute at the base, sub-coriaceous, greenish-brown, lustrous and rather obscurely reticulate-veined above, rustybrown and reticulate-veined beneath; petioles slender, $7 \mathrm{~mm}$. long; drupes ellipsoid, I I-I $3 \mathrm{~mm}$. long, 4.5-5 mm. thick.

Type collected at Caleta Grande, Isle of Pines (Roig \& Cremata $I 856)$.

Erythroxylon coriaceum Britton \& Wilson, sp. nov.

A small tree, 5-7 m. high, with rather stiff gray branches. Leaves elliptic-obovate to obovate, $2.5-5.5 \mathrm{~cm}$. long, $1.5-3.4 \mathrm{~cm}$. broad, rounded and often emarginate at the apex, obtuse or somewhat acute at the base, coriaceous, indistinctly veined, dark green above, paler beneath, the margin revolute; petioles 5-7 $\mathrm{mm}$. long; stipules triangular, 2-3 $\mathrm{mm}$. long; buds several together in the axils, on short pedicels; calyx-lobes ovate, acute; drupes (undeveloped?) narrowly oblong, about I cm. long, orange-red.

Type collected on bank of Rio Guayabo, above the falls, Oriente (Shafer $360 I$ ).

\section{Family BURSERACEAE}

Elaphrium Shaferi Britton \& Wilson, sp. nov.

A glabrous tree $6 \mathrm{~m}$. in height; bark of the trunk reddishbrown, easily, peeling off in thin sheets; branches brown; leaves simple, narrowly deltoid-lanceolate, $4-8 \mathrm{~cm}$. long, I-I.S mm. broad at the base, acuminate at the apex, rounded and cordate at the base, reticulate-veined above, the lateral veins nearly at right angles to the midvein; reticulate-veined beneath; petioles slender, I-I.5 cm. long; inflorescence about I-I.5 cm. long; drupes obovoid, 6.5-7 mm. long, $5 \mathrm{~mm}$. broad. 
In dry rocky places, La Guira, north of Sumidero, Pinar del Rio (Shafer I375I).

\section{Family MALPIGHIACEAE}

Bunchosia Leonis Britton \& Wilson, sp. nov.

Shrub I m. tall, with grayish-brown twigs. Leaves obovate, I-3.2 cm. long, rounded and emarginate at the apex, cuneate at the base, coriaceous, lustrous above, dull beneath, glabrous in age, short-petioled; flowering pedicels pubescent; corolla about I-I.3 cm. broad; sepals ovate, $2.5 \mathrm{~mm}$. long, ciliate, the glands one-half the length of the sepal body; larger petals $5-5.5 \mathrm{~mm}$. long, the blades suborbicular, toothed; ovary and style glabrous; drupes $1.6-2 \mathrm{~cm}$. long.

Type collected in coastal thicket, Playa del Chivo, Havana (Léon 7214).

\section{Family EUPHORBIACEAE}

Andrachne (?) cuneifolia Britton, sp. nov.

A glabrous shrub I-2 $\mathrm{m}$. high, with slender elongated leafy branches. Leaves obovate, cuneate, 5-12 $\mathrm{mm}$. long, rounded at the apex, delicately pinnately veined, dark green and shining above, pale green and dull beneath, the petiole about I mm. long; stipules minute; fruiting pedicels about $\mathrm{I} 4 \mathrm{~mm}$. long, the six persistent oblong sepals about I mm. long.

Punta Maisi, Oriente: southern and southwestern Porto Rico. Type from a dry hillside, Coamo Springs, Porto Rico (Underwood \& Griggs 545).

RAMSDENIA Britton, gen. nov.

Monoecious shrubs, with flattened branches, distichous, emarginate, orbicular or obovate leaves, or those of primary branches reduced to scales, the apetalous flowers solitary or 2 together in the axils, the pistillate few. Sepals 5, coriaceous. Stamens 5, the filaments connate, the anthers extrorse. Styles several-cleft. [In honor of Charles T. Ramsden, distinguished Cuban zoologist.]

Type species: Phyllanthus excisus Urban.

Ramsdenia excisa (Urban) Britton, comb. nov.

Phyllanthus excisus Urban, Repertorium I3: 449. I9I4. 
In rich woods, Navas to Camp Buena Vista, Oriente. Endemic. A shrub about $3 \mathrm{~m}$. high.

Ramsdenia incrustata (Urban) Britton, comb. nov.

Phyllanthus incrustatus Urban, Repertorium I3: 449. I9I4.

Moist woods, mountains of northern Oriente. Endemic.

Orbicularia scopulorum Britton, sp. nov.

A shrub, $2 \mathrm{~m}$. high, with slender, ascending branches and very slender leafy twigs; stipules setaceous, deflexed, 3-4 mm. long; leaves spatulate-obovate, 5-7 mm. long, nearly sessile, distichous, minutely foveolate and inconspicuously veined above, distinctly pinnately veined beneath; rounded at the apex, cuneate at the base; flowers and fruit unknown.

Rocky thickets near Camp Toa, Oriente, at about $400 \mathrm{~m}$. altitude (Shafer 4006).

Orbicularia foveolata Britton, sp. nov.

A vine-like shrub, with short, ascending branches, the twigs very slender. Stipules subsetaceous, about I mm. long. Leaves coriaceous, orbicular-obovate or elliptic-orbicular, nearly sessile, 8-I2 mm. long, shining, inconspicuously veined and distinctly foveolate above, dull, and prominently veined beneath, rounded at the apex, obtuse at the base; flowers and fruit unknown.

Camp La Gloria, south of Sierra Moa, Oriente (Shafer 827I).

\section{ROIGIA Britton, gen. nov.}

A shrub with dimorphous branches, the narrowly spatulate, entire leaves spirally arranged on the short secondary branches, the staminate flowers long-peduncled, solitary in the axils. Staminate flowers with a 6-parted calyx, the segments obovate, rounded, erose; stamens IO, the filaments united into a long column, free above; anthers suborbicular. [In honor of Juan T. Roig, enthusiastic Cuban botanist.] A monotypic genus.

Roigia comosa (Urban) Britton, comb. nov.

Phyllanthus comosus Urban, Repertorium I3: 45I. I9I4.

Dry rocky soil, serpentine hills near mouth of Rio Yamaniguey, Oriente. Endemic.

Conami (?) ovalifolia Britton, sp. nov.

A glabrous undershrub, I $\mathrm{m}$. high or less, the stem rather stout, the branches mostly simple, elongated, slender, compressed 
and somewhat angled. Leaves chartaceous, distichous, oval to elliptic, 4-8 cm. long, $2-4 \mathrm{~cm}$. wide, rounded at the apex, obtuse or narrowed at the base, pinnately veined; stipules clustered at the end of the stem, lanceolate, acuminate, striate, I-I.5 cm. long; flowers fascicled in the axils, reddish, the slender pedicels 3-6 $\mathrm{mm}$. long; perianth-segments 4 , those of pistillate flowers suborbicular, rounded, about $4 \mathrm{~mm}$. long, larger than the staminate; styles united; stigmas 3 , short, spreading; filaments united; anthers 2.

Valleys, northern Oriente: type collected between Yamuri Arriba and Bermejal (Shafer 8446).

\section{DIMORPHOCLADIUM Britton, gen. nov.}

A shrub, with dimorphous branches and leaves. Primary branches stout, terete, their leaves oblong-spatulate, densely arranged spirally. Secondary branches very slender, compressed, their small oblong-obovate leaves distichous. Staminate flowers pedicelled, clustered in the axils; sepals 5, ovate. Stamens 4, the filaments connate, the anthers free, subquadrate. [Greek, dimorphous branches.] A monotypic genus.

Dimorphocladium formosum (Urban) Britton, comb. nov.

Phyllanthus formosus Urban, Repertorium I3: 45I. I9I4.

Thickets between Camp La Barga and Camp San Benito, Oriente. Endemic. A shrub 4-6 dm. high, the flowers pink.

Phyllanthus Selbyi Britton \& Wilson, sp. nov.

A glabrous, perennial herb, $4 \mathrm{dm}$. tall, with ascending, slightly flexuose, woody branches; the slender leafy twigs $1.5-3 \mathrm{~cm}$. long. Leaves elliptic to oval, $2-2.5 \mathrm{~mm}$. long, $1.3-1.6 \mathrm{~mm}$. broad, obtuse at the apex, rounded or somewhat truncate at the base, short-petioled, coriaceous, veinless or nearly so; stipules linearlanceolate, I mm. long; flowers monoecious; pistillate flowers short-pedicelled, the sepals obovate, I.3-1.5 mm. long, $0.5 \mathrm{~mm}$. broad; ovary depressed-globose; styles 3 , forked near the top; staminate flowers short-pedicelled, the sepals broadly ovate, I.2 $\mathrm{mm}$. long, 0.9-I mm. broad; filaments united with a short column ; anthers 3 ; capsule depressed-globose, about $1.8 \mathrm{~mm}$. broad; seeds brown, about I mm. long, transversely striate.

White sand, vicinity of San Pedro, Isle of Pines (Britton, Wilson \& Selby I4I57). 


\section{Phyllanthus dimorphus Britton \& Wilson, sp. nov.}

A glabrous perennial herb, 5-6 dm. tall, with slender woody stems branching mostly near the apex, the slender branches straight, ascending or spreading, 8-14 cm. long. Leaves oblong or elliptic-oblong, 5-9 mm. long, 2-2.5 mm. broad, short-petioled, rounded or occasionally somewhat acutish at the apex, rounded at the base, dark-green above, paler beneath; stipules narrowly lanceolate, I-I.5 mm. long, purplish-black; flowers dioecious; pistillate flowers slender-pedicelled, their sepals obovate to broadly obovate, $2 \mathrm{~mm}$. long, I-I.5 $\mathrm{mm}$. broad, rounded at the apex; styles of flowers of some plants 3 , slender, forked above the middle; of other plants united into a column about I mm. long, the stigma orbicular, peltate, entire; staminate flowers not seen.

Grassy hill between E1 Porvenir and Aguacate, Trinidad mountains, Santa Clara, 700-900 m. altitude (Britton \& Wilson 5350).

Croton cueroensis Britton \& Wilson, sp. nov.

Shrub $2 \mathrm{~m}$. tall; the twigs and petioles densely ferruginoushispid with stellate hairs when young, grayish in age. Leaves broadly ovate to suborbicular, I.8-3.4 cm. long, I.5-2.8 cm. broad, more or less soft pubescent above with stellate hairs, stellate-canescent beneath; petioles $0.8-1.5 \mathrm{~cm}$. long; stipules subulate, broadening at the base, 7-II.5 mm. long; buds subglobose, flattened; sepals of the staminate flowers ovate; filaments tomentose; capsule densely stellate-tomentose; seed short-ovoid, 3.5 $\mathrm{mm}$. long, $3 \mathrm{~mm}$. broad, grayish.

\section{Vicinity of E1 Cuero, Oriente (Britton \& Cozvell I2735).}

Differing from $C$. spiralis Muell. Arg. in the long, subulate stipule which is not coiled at the base, also by the stellate hairs of the upper surface, which are long-rayed.

\section{Argythamnia cubensis Britton \& Wilson, sp. nov.}

A small shrub with brownish or purplish-brown decumbent branches; leaves elliptic to oval or obovate, I-2.5 cm. long, $0.5-1.4$ $\mathrm{cm}$. broad, rounded or acute at the apex, acute at the base, entire or crenulate, short-petioled, purplish-brown and more or less strigillose on both surfaces; staminate flowers about $2 \mathrm{~mm}$. broad; sepals 5 , lanceolate, I-I.2 mm. long, $0.5 \mathrm{~mm}$. broad; petals 5, ovate, I-I.I mm. long, $0.5-0.6 \mathrm{~mm}$. broad; stamens 5 , the filaments distinct; sepals of the pistillate flowers 5 , ovate, acuminate at the apex; styles 3 , distinct, bifid ; capsule about $3 \mathrm{~mm}$. in diameter; seeds subglobose, I.I-I.2 mm. broad, reticulated. 
Rocky coastal hills, vicinity of El Morro, Santiago Bay, Oriente (Britton \& Cowell I2580).

Lasiocroton gracilis Britton \& Wilson, sp. nov.

Shrub, the young twigs clothed with minute, ferruginous, stellate hairs; leaves ovate, $3-3.5 \mathrm{~cm}$. long, I.4-2.5 cm. broad, acute to short-acuminate at the apex, rounded or subcordate at the base, short-petioled, those on the branches oblong-elliptic, I-I.5 $\mathrm{cm}$. long, $0.5 \mathrm{~cm}$. broad, all entire and glabrous or nearly so above, beneath reticulate-veined and densely stellate-pubescent with whitish hairs; inflorescence slender, 3-5 cm. long, loosely flowered; petals of the staminate flowers ovate-lanceolate, $2 \mathrm{~mm}$. long, I mm. broad, acute at the apex, densely pubescent on the back; fruit not seen.

Type collected in the vicinity of Santiago, Oriente (Pollard \& Palmer 28I).

Lasiocroton (?) cordifolius Britton \& Wilson, sp. nov.

A shrub 2-2.5 m. tall, the young twigs densely clothed with short, ferruginous, stellate hairs; leaves broadly ovate-oval to oval, 7-I $4 \mathrm{~cm}$. long, 4.5-10.5 cm. broad, obtuse, acute or shortacuminate at the apex, rounded and cordate at the base, entire, above glabrous; the veins rather inconspicuous, beneath stellatepubescent with whitish hairs, the midvein and lateral veins prominent; petioles $4-5.5 \mathrm{~cm}$. long, densely short-stellate pubescent; flowers and fruit not seen.

Along stream in the Pinales southeast of Paso Estancia, Oriente (Shafer I724).

Pera longipes Britton \& Wilson, sp. nov.

A shrub about $3 \mathrm{~m}$. high, with slender, ascending, glabrous twigs. Leaves alternate, obovate, coriaceous, $3-7 \mathrm{~cm}$. long, I-3 $\mathrm{cm}$. wide, green on both sides, elepidote, rounded or emarginate at the apex, cuneate at the base, faintly pinnately few-veined, the stout petiole $1.5-2.5 \mathrm{~mm}$. long; staminate inflorescence longpeduncled, subglobose, I-bracted, about $4 \mathrm{~mm}$. in diameter, sparingly lepidote; peduncle weak, curved or flexuous, $1.5^{-2} \mathrm{~cm}$. long ; bract ovate-orbicular, rounded, lepidote, I.5 mm. long:

Dry serpentine thickets, between Navas and Camp Buena Vista, Oriente, at 650 meters altitude (Shafer 44I6).

Pera pallidifolia Britton \& Wilson, sp. nov.

A shrub, 2-2.6 m. high, with slender, ascending twigs. Leaves alternate, oblong-oblanceolate, subcoriaceous, $4-8 \mathrm{~cm}$. 
long, I-2.2 cm. wide, pale green on both sides, pinnately fewveined, elepidote, obtuse or rounded at the apex, narrowed at the base, the rather slender petioles 5-10 $\mathrm{mm}$. long; peduncles of the staminate inflorescence straight, lepidote, 6-8 $\mathrm{mm}$. long; staminate involucre I-bracted or with a second minute bract, rather densely lepidote, depressed-globose, about $2 \mathrm{~mm}$. in diameter.

Dry hillsides between Rio Yamaniguey and Camp Toa, Oriente, at 400 meters altitude (Shafer $418_{3}$ ).

Sapium cubense Britton \& Wilson, sp. nov.

A glabrous milky shub or a small tree up to $6 \mathrm{~m}$. high, the slender twigs subterete. Leaves subcoriaceous, oblong to oblongobovate, $8 \mathrm{~cm}$. long or less, $1.5-3 \mathrm{~cm}$. wide, acute or obtuse at the apex, narrowed or subcuneate at the base, glandular-crenulate, the midvein prominent, the lateral venation obscure, the slender, eglandular petiole 8-I $5 \mathrm{~mm}$. long; spikes slender, interrupted, axillary, about as long as the leaves or shorter; calyx about I $\mathrm{mm}$. long; filaments $2-3$ times as long as the calyx; valves of the capsule about $7 \mathrm{~mm}$. long.

Woods and thickets, northern Oriente. Type from near Woodfred, Sierra Nipe (Shafer 3607).

Acalypha Hutchinsonii Britton, sp. nov.

Perennial, apparently dioecious, depressed, velvety-pubescent, branched, the branches slender, prostrate or ascending, $4-8 \mathrm{~cm}$. long. Leaves ovate-orbicular, 5-I $5 \mathrm{~mm}$. long, crenate-serrate, obtuse or acutish at the apex, subtruncate at the base, the petioles I-3 mm. long; staminate spike short-peduncled, 6-9 mm. long.

Rocks on the coast of southern Santa Clara (Britton, Earle \& Wilson 5907).

The species appears to be distinct from any of those described by Prain and Hutchinson in Kew Bulletin I9I3: I-28.

\section{Family CYRILLACEAE}

Cyrilla cubensis $\mathrm{P}$. Wilson, sp. nov.

A glabrous shrub I-2 m. tall, with grayish more or less angled twigs. Leaves elliptic-obovate, I.5-3 cm. long, 0.9-2 cm. broad, rigidly coriaceous, rounded and emarginate at the apex, acute or rounded at the base, dark green and shining above, the veins rather inconspicuous, paler, papillose and reticulate-veined be- 
neath; midrib impressed above, prominent beneath; racemes stout, 3.5-4 cm. long, many-flowered, erect, glabrous; bracts narrowly lanceolate, I.5 mm. long; pedicels $2.5-3 \mathrm{~mm}$. long; calyxlobes ovate-lanceolate, short-acuminate; petals elliptic or ellipticovate, $3-3.2 \mathrm{~mm}$. long, I. $2 \mathrm{~mm}$. broad, acute; stamens about half as long as the petals; ovary glabrous.

Mountains of Oriente (Shafer 4I40, type; 4I09, 4060).

\section{Family ILICACEAE}

Ilex Shaferi Britton \& Wilson, sp. nov.

A small shrub, I-3 $\mathrm{m}$. high, with grayish branches and puberulent twigs. Leaves obovate, $0.6-\mathrm{I} .4 \mathrm{~cm}$. long, $0.5-0.8 \mathrm{~cm}$. broad, with entire revolute margins, rounded and often emarginate at the apex, cuneate at the base, short-petioled, glabrous, shining and obscurely veined above, paler, lustrous and obscurely veined beneath; fruit subglobose, solitary in the axils of the leaves, 6-7 mm. long, 5-7 mm. in diameter, dark red.

Mountains of Oriente (Shafer 804I, type; 4065 and 4I26).

Ilex Clementis Britton \& Wilson, sp. nov.

A shrub several meters high. Leaves elliptic to ovate-oval or somewhat obovate, $4.5-9 \mathrm{~cm}$. long, $2.5-5 \mathrm{~cm}$. broad, rounded or acutish and usually apiculate at the apex, cuneate or rounded at the base, entire, glabrous, dull above, the midvein impressed, reticulate-veined and paler beneath; pedicels minutely puberulent, 3-5 mm. long; staminate flowers fascicled in the axils of the leaves; sepals 4, suborbicular, I.5-2 $\mathrm{mm}$. broad, strongly imbricate, ciliate; corolla lobes 4 , elliptic to oval, $2-2.2 \mathrm{~mm}$. long; fruit unknown.

Mountains of Santa Clara (Brothers Léon and Clement 6645, type; 6558, 6669 and 6694).

\section{Family HIPPOCRATEACEAE}

Salacia (?) nipensis Britton, sp. nov.

A woody vine, sometimes $3 \mathrm{~m}$. long, the twigs warty. Leaves coriaceous, glabrous, entire, elongate-lanceolate, 6-18 cm. long, I.5-4 cm. wide, obtuse at the apex, cordate at the base, pinnately veined, the midvein prominent, the lateral venation obscure; petioles stout, only $2 \mathrm{~mm}$. long; fruit oblong, obtuse, slightly narrowed towards the base, about $4 \mathrm{~cm}$. long and $1.5 \mathrm{~cm}$. in diameter, scurfy; sepals persistent, suborbicular, about $3 \mathrm{~mm}$. broad. 
Dry, rocky hillside, Sierra Nipe, Piedra Gorda to Woodfred, Oriente (Shafer $3{ }^{18} 3$ ).

\section{Family RHAMNACEAE}

Sarcomphalus cubensis Britton, sp. nov.

A glabrous tree about Io $\mathrm{m}$. high, the twigs rather stout, stiff, somewhat angled. Leaves borne on short spurs, elliptic or obovate-elliptic, slightly fleshy, $\mathrm{I} .5-3.5 \mathrm{~cm}$. long, rounded or emarginate at the apex, obtuse or somewhat narrowed at the base, faintly pinnately veined with the lower pair of veins the strongest, the midvein rather prominent beneath, the slender petioles $3-5 \mathrm{~mm}$. long; fruiting pedicels very slender, 8-12 mm. long; fruit ovoid, 6-8 $\mathrm{mm}$. long, short-tipped, about 3 times as long as the calyx.

Coastal thickets, Oriente, Santa Clara. Type from Punta Piedra, Nipe Bay, Oriente (Britton \& Cowell 12486).

Rhamnidium (?) oblongifolium Britton \& Wilson, sp. nov.

A shrub I m. tall, with puberulent twigs; leaves oblong, occasionally somewhat elliptic-oblong, $0.9-2.5 \mathrm{~cm}$. long, 3-6 $\mathrm{mm}$. broad, rounded and emarginate at the apex, obtuse at the base, entire, green and lustrous above, whitish and conspicuously blackdotted beneath, glabrous; petioles I-2.5 $\mathrm{mm}$. long, puberulent; flower-clusters axillary, long-peduncled; sepals triangular-ovate, acuminate, glabrous, glandular-dotted; petals broadly triangularobovate; filaments subulate; anthers ovate; ovary ovoid, glabrous, black-dotted.

Rocky hill, palm barren, Santa Clara (Britton \& Cowell I33II).

Rhamnidium (?) orbiculatum Britton \& Wilson, sp. nov.

An erect shrub, $2 \mathrm{~m}$. tall, with grayish-brown, glabrous twigs; leaves oval to orbicular-oval, I.5-2.5 cm. long, I.5-2.4 cm. broad, rounded and emarginate at the apex, rounded at the base, lustrous, reticulate-veined and black-dotted above, paler, blackdotted and dull beneath, glabrous; petioles 5-6 mm. long; flowerclusters axillary, long-peduncled; sepals ovate, glabrous, blackdotted; petals present; filaments short, anthers ovate.

Dry soil, savannas near Camaguey (Britton \& Cowell I3I88).

Rhamnidium Rocanum Britton \& Wilson, sp. nov.

A shrub with slender grayish-brown puberulent twigs. Leaves oblong-elliptic, 7-Io cm. long, $2.4-3.5 \mathrm{~cm}$. broad, rounded or occa- 
sionally acutish and mucronulate at the apex, rounded at the base, entire, glabrous, reticulate-veined and tuberculate above, sparingly puberulent and conspicuously black-dotted beneath; petioles 6-8 $\mathrm{mm}$. long; flower-clusters axillary, on peduncles about $\mathrm{I} \mathrm{cm}$. long; flowers immature; sepals triangular-ovate, acute, glandulardotted; petals orbicular-obovate; filaments subulate, glabrous; anthers ovate; ovary ovoid, compressed, glabrous, glandulardotted.

In woods, Banao Mountains, Santa Clara (Léon \& Roca 8052).

\section{Family VITACEAE}

Cissus Torreana Britton \& Wilson, sp. nov.

A vine several meters long, with loosely hirsute, winged branches; leaves 3 -foliolate; petioles $8-10 \mathrm{~cm}$. long, winged; leaflets membranaceous, elliptic-ovate to obliquely ovate, 8-II $\mathrm{cm}$. long, 5-7 cm. broad, acuminate at the apex, obliquely rounded or acutish at the base, puberulent above, loosely hirsute on the veins beneath, the margin serrulate; petiolules about $1.5 \mathrm{~cm}$. long, hirsute; flowers and fruit not seen.

Type from Sierra del Grillo, Madruga, Havana (Léon \& de la Torre 6345).

\section{Family MALVACEAE}

Malache calcicola Britton, sp. nov.

A shrub, $2 \mathrm{~m}$. high, the twigs, petioles and leaf-surfaces densely puberulent and bearing scattered, large stellate hairs. Leaves ovate-orbicular, $\mathrm{I}-3 \mathrm{~cm}$. long, irregularly dentate and mostly 3-lobed, acute or acuminate at the apex, cordate at the base, green above, nearly white beneath; the petioles shorter than the blades; flowers solitary, slender-peduncled, the peduncles jointed somewhat below the calyx; bractlets 5, linear, puberulent, appressed, a little shorter than the calyx; calyx puberulent and stellate-pubescent 5 -lobed, 6-7 mm. long, its lobes ovate, acute; petals red, strongly veined, about twice as long as the calyx; stamen-column about twice as long as the petals; style-branches IO, slender, $2 \mathrm{~cm}$. long; carpels 5, dry coriaceous, irregularly rugose-crested on the sides, sharply and narrowly winged on the back, short-beaked, $6 \mathrm{~mm}$. long, I-seeded, dehiscent; seed obliquely ovoid, brown, shining, smooth, $3 \mathrm{~mm}$. long.

Base of cliff, Rio San Juan, Santa Clara (Britton, Earle \& Wilson 5905.) 
Maga cubensis Britton \& Wilson, sp. nov.

A tree, up to $15 \mathrm{~m}$. high, the stout twigs densely and finely lepidote. Leaves ovate-orbicular, deeply cordate, acute or acuminate, coriaceous, entire, 6-12 cm. long, strongly palmately 5-7veined, the veins enlarged and united at the base beneath, dull and finely reticulate-veined above, densely and finely lepidote beneath, the terete, lepidote petioles Io $\mathrm{cm}$. long or less; flowers solitary or clustered, on stout, lepidote peduncles $\mathrm{I}-6 \mathrm{~cm}$. long; calyx subcampanulate, lepidote, about $12 \mathrm{~mm}$. long, nearly truncate, with 5 subulate teeth, circumscissile at the base and wholly deciduous; petals brown-yellow, rounded, finely many-veined, about $3 \mathrm{~mm}$. long, densely lepidote without; stamen-column about twice as long as the petals; stamens yellow.

Coastal thickets, and low woodlands, Camaguey; Santa Clara. Type from Punta Diablo, Cienfuegos Bay, Santa Clara (Britton \& Wilson 6045).

\section{Family STERCULIACEAE}

Melochia savannarum Britton, sp. nov.

A low, more or less prostrate undershrub, the young branches finely stellate-pubescent, often with simple hairs intermixed; leaves ovate to broadly oval, $\mathrm{I}-2 \mathrm{~cm}$. long, $0.7-2 \mathrm{~cm}$. broad, acute or rounded at the apex, truncate, rounded or cordate at the base, rather coarsely serrate, glabrous or loosely pubescent above with simple and stellate hairs, more or less pubescent beneath; petioles 3-5 mm. long; flowers short-pedicelled; calyx-teeth triangularsubulate; petals narrowly obovate, $6.5-7 \mathrm{~mm}$. long, $1.5^{-2} \mathrm{~mm}$. broad; ovary tomentose.

Savannas and along streams, Pinar del Rio. Type from Herradura, Pinar del Rio (Earle 639).

Recorded by Grisebach as $M$. melissifolia Benth. and referred by Wright to $M$. hirsuta Cav.

Melochia nipensis Britton, sp. nov.

Perennial; herbaceous with a deep slender tap-root, branches ascending or spreading, very slender, villous and tomentose, 2.5 $\mathrm{dm}$. long or less. Leaves oval or oblong, 6-16 mm. long, 4-7 $\mathrm{mm}$. wide, tomentose on both sides, obtuse at the apex, somewhat narrowed at the base, serrulate, the villous petioles $2.5 \mathrm{~mm}$. long or less; flowers few, glomerate; bracts narrowly linear; calyx about $3 \mathrm{~mm}$. long, its lance-subulate teeth about as long as the tube; petals spatulate, yellow, $3 \mathrm{~mm}$. long. 
Pinelands, Sierra Nipe, near Woodfred, Oriente (Shafer 3294).

\section{Family OCHNACEAE}

Ouratea affinis Britton, sp. nov.

A tree $3-5 \mathrm{~m}$. high, the twigs slender, gray. Leaves coriaceous, lanceolate or oblong-lanceolate, $4-7 \mathrm{~cm}$. long, $2 \mathrm{~cm}$. wide or less, entire, acuminate at the apex, obtuse or narrowed at the base, dull, faintly and closely pinnately straite-nerved, the midvein rather prominent; petioles 3-6 $\mathrm{mm}$. long; fruiting pedicels 2-6 mm. long; receptacle subglobose, 5-6 $\mathrm{mm}$. in diameter.

Mountains of northern Oriente. Type from Rio Naranja at 450-550 m. altitude (Shafer 3869).

\section{Ouratea Roigii Britton, sp. nov.}

Twigs gray, slender. Leaves lanceolate, chartaceous, dull, 4-7 cm. long, I. $-2.5 \mathrm{~cm}$. wide, acuminate at the apex, narrowed or rounded at the base, pinnately veined and reticulated, the venation rather prominent beneath, the petioles $4-8 \mathrm{~mm}$. long; fruiting pedicels 2-4 cm. long; receptacle subglobose, about $6 \mathrm{~mm}$. in diameter.

Canete, Baracoa, Oriente (Roig 67).

\section{Family MARCGRAVIACEAE}

Marcgravia calcicola Britton, sp. nov.

Barren climbing branches very slender, $3 \mathrm{dm}$. long or longer, their leaves sessile, ovate, cordate, acute, about $2 \mathrm{~cm}$. long. Flowering branches slender, gray, their leaves oblong, 5-6 cm. long, I $2-20 \mathrm{~mm}$. wide, acute at both ends, the midvein prominent beneath, impressed above, the lateral venation wholly obscure, the petioles I-2 $\mathrm{mm}$. long, uppermost leaves ovate, 2-3 cm. long; raceme short, several-many-flowered; pedicels rather stout, thickened upward, I-I.5 cm. long; sepals suborbicular, rounded; corolla-bud rounded; sterile pedicels incurved, I $\mathrm{cm}$. long or less; bracts galeate, compressed, $6 \mathrm{~mm}$. broad.

Limestone cliffs, Baños San Vicente, Pinar del Rio (Britton \& Gager 74I2).

\section{Family THEACEAE}

Haemocharis benitoensis Britton \& Wilson, sp. nov.

A straggling shrub, I-2 $\mathrm{m}$. high, with slender branches, the twigs pilose with appressed hairs; leaves obovate, $3-5 \mathrm{~cm}$. long, 
I-I. $6 \mathrm{~cm}$. broad, rounded at the apex, cuneate at the base, yellowish-green and glabrous above, the midvein impressed, paler and often loosely pilose beneath, the midvein prominent, the lateral veins indistinct; margin more or less revolute; petioles slender, 5-7 mm. long, pilose; sepals suborbicular, $3 \mathrm{~mm}$. long, appressed-pilose on the back; petals elliptic-obovate or obovate, I cm. long, 5-6 mm. broad, "white"; ovary appressed-pilose.

Type from thicket, vicinity of Camp San Benito, Oriente (Shafer 4063).

\section{Family CLUSIACEAE}

Rheedia brevipes Britton, sp. nov.

A tree about $4 \mathrm{~m}$. high, the twigs short; leaves opposite, borne in 2-4 pairs near the ends of the twigs, rigid, oblong-lanceolate to ovate-lanceolate, $4-6 \mathrm{~cm}$. long, $\mathrm{I}-2.5 \mathrm{~cm}$. wide, pinnately veined, acuminate, spinulose-tipped, narrowed or obtuse at the base, the stout petiole about $3 \mathrm{~mm}$. long; staminate flowers solitary or few together on pedicels $3 \mathrm{~mm}$. long; flower-bud subglobose, 2.5-3 $\mathrm{mm}$. in diameter; sepals suborbicular, rounded.

Bank of arroyo, between Santa Clara and Manicaragua, Santa Clara (Britton \& Cowell I0262).

Clusia callosa Britton \& Wilson, sp. nov.

A glabrous shrub, 2-3 m. tall, with rather thick, more or less angled, grayish, branches; leaves broadly obovate, $4-6.5 \mathrm{~cm}$. long, $2.7-4.5 \mathrm{~cm}$. broad, rigid-coriaceous, rounded at the apex, obtuse at the base, lustrous above, the veins rather indistinct, paler beneath and conspicuously black glandular-dotted, the midvein prominent, vanishing at or above the middle, the lateral veins obscure or indistinct, the margin revolute and conspicuously thickened; inflorescence terminal, 6-7 cm. long; stigmas 5 ; fruit subglobose or globose-obovoid, I.5 cm. long, I.2-I.5 cm. broad.

Type from Camp La Gloria, south of Sierra Moa, Oriente (Shafer 8206).

\section{Family HYPERICACEAE}

Hypericum ophiticola Britton, sp. nov.

Perennial by a deep slender root, much branched, the stems angular, slender, prostrate or ascending, $5^{-15} \mathrm{~cm}$. long, the branches short, ascending or erect, rather densely leafy. Leaves oblanceolate, 2-2.5 mm. long, sessile, rounded at the apex, nar- 
rowed at the base, I-nerved, black-punctate; flowers terminal, solitary, short-peduncled; sepals obovate-oblong, apiculate, I-nerved, $2.5 \mathrm{~mm}$. long; capsule oblong, 3-valved, about as long as the sepals.

Hillside, serpentine palm barren, Santa Clara (Britton \& Wilson 6I40).

\section{Family FLACOURTIACEAE}

\section{Myroxylon (?) rhombifolium Britton \& Wilson, sp. nov.}

A shrub about I $\mathrm{m}$. high, with very slender, elongated, puberulent branches, each node with an acicular spine 8-12 $\mathrm{mm}$. long, Leaves coriaceous, rhombic, 6-10 $\mathrm{mm}$. broad, about as long as wide, 2-5-toothed, strongly veined on both sides, the venation somewhat reticulated, dark green and shining above, pale green beneath, glabrous, the petioles $0.5^{-1} \mathrm{~mm}$. long; flowers and fruit unknown.

Coe's Camp, Ensenada de Siguanea, Isle of Pines (Britton \& Wilson I4880).

Lunania subcoriacea Britton \& Wilson, sp. nov.

A shrub, about $3 \mathrm{~m}$. high, with slender gray terete branches. Leaves oblong-lanceolate, subcoriaceous, glabrous, $12-17 \mathrm{~cm}$. long, 4-5 cm. wide, acute or short-acuminate at the apex, obtuse or rounded at the base, the rather stout petioles $I-I .5 \mathrm{~cm}$. long; raceme peduncled, about Io $\mathrm{cm}$. long, glabrous; pedicels $4.5-5$ $\mathrm{mm}$. long, jointed near the base, glabrous; sepals orbicular or suborbicular, $4.5 \mathrm{~mm}$. broad, concave; filaments subulate; disk fleshy; ovary ovoid.

Rich woods, alluvial valley of Rio Yamaniguey, Oriente (Shafer 4204).

Lunania elongata Britton \& Wilson, sp. nov.

Branches slender, elongated, puberulent when young, gray, terete. Leaves lanceolate or oblong-lanceolate, membranous, glabrous, 5-I $5 \mathrm{~cm}$. long, $3 \mathrm{~cm}$. wide or less, acuminate at the apex, rounded or subcordate at the base, the slender petioles $8-20 \mathrm{~mm}$. long, puberulent when young; raceme long-peduncled, narrow, puberulent, many-flowered, IO-I8 cm. long; pedicels $2-3 \mathrm{~mm}$. long, jointed above the base, puberulent; sepals orbicular, $4 \mathrm{~mm}$. broad, concave; stamens about IO; disk fleshy; ovary ellipticovoid.

Sierra de las Divisiones, Sancti Spiritus mountains, Santa Clara (Léon and Clement 6598). 


\section{Family THYMELAEACEAE}

Daphnopsis oblongifolia Britton \& Wilson, sp. nov.

A shrub I-2 m. or more high, with slender branches, the young growth appressed-puberulent. Leaves linear-oblong to oblong or somewhat elliptic-oblong, $2-5.5 \mathrm{~cm}$. long, 4-7 $\mathrm{mm}$. broad, obtuse or acutish at the apex, acute at the base, short-petioled, entire, revolute-margined, the veins anastomosing and nearly parallel to the midrib; inflorescence short-peduncled, few-flowered; pedicels $2-2.5 \mathrm{~mm}$. long, staminate flowers with calyx-tube short, the lobes ovate.

Type from palm barren, Santa Clara (Britton \& Cowell I330I).

\section{Family MYRTACEAE}

Psidium nummularioides Britton \& Wilson, sp. nov.

A snall tree, with slender, gray, terete, glabrous twigs. Leaves orbicular or ovate, coriaceous, glabrous, 8-I $5 \mathrm{~mm}$. long, rounded or obtuse at the apex, rounded or subcordate at the base, bright green and finely reticulate-veined on both surfaces, the midvein rather prominent, the stout petioles about I mm. long; pedicels axillary, solitary, slender, ascending, $1.5 \mathrm{~cm}$. long; calyx-lobes suborbicular, 2-2.5 mm. long, 3-3.5 mm. broad, glabrous; young fruit ellipsoid, $8 \mathrm{~mm}$. long, $5-6 \mathrm{~mm}$. in diameter.

Coral limestone bench, Guantanamo Bay, Oriente (Britton 2046).

Psidium (?) navasense Britton \& Wilson, sp. nov.

A glabrous shrub, about $1.3 \mathrm{~m}$. high, the slender twigs terete. Leaves oblong-lanceolate or ovate-lanceolate, subcoriaceous, $5-7$ $\mathrm{cm}$. long, dull, bluntly acuminate at the apex, obtuse at the base, rather strongly pinnately veined with the veins united near the margin, the midvein impressed above, prominent beneath, the stout petioles about $2 \mathrm{~mm}$. long; young fruits axillary, solitary, subglobose, about $7 \mathrm{~mm}$. in diameter, on peduncles $6-8 \mathrm{~mm}$. long; calyx-lobes suborbicular, $2 \mathrm{~mm}$. long, $2-2.5 \mathrm{~mm}$. broad; berry subglobose, $6 \mathrm{~mm}$. in diameter.

Moist woods between Navas and Camp Buena Vista, Oriente, $650 \mathrm{~m}$. altitude (Shafer 4444).

Psidium bullatum Britton \& Wilson, sp. nov.

A shrub or a tree up to $5 \mathrm{~m}$. high, the young twigs densely short-pubescent, terete. Leaves ovate or ovate-elliptic, $3-5 \mathrm{~cm}$. 
long, mostly obtuse at the apex, rounded or subcordate at the base, revolute-margined, very short-petioled, when young thin, densely puberulent above, white-tomentulose and black-dotted beneath, when old coriaceous, glabrous and shining with the veins deeply impressed above, dull, glabrate, with the veins very prominent beneath; flowers axillary or lateral on rather stout pubescent peduncles, $1.5-3 \mathrm{~cm}$. long, 2-bracted at the summit, the bracts ovate-oblong, $4 \mathrm{~mm}$. long, deciduous ; calyx densely white-tomentulose and black-dotted, $6 \mathrm{~mm}$. long, open in the bud; petals white, somewhat longer than the calyx; ovary 2-celled; fruit ellipsoid, about I cm. long, the calyx persistent.

Palm barrens, Camaguey, Santa Clara. Type from Santa Clara (Britton \& Cowell I3328).

Psidium (?) ophiticola Britton \& Wilson, sp. nov.

A shrub, about $2 \mathrm{dm}$. high, the twigs densely tomentulose, terete. Leaves mostly elliptic, coriaceous, $4 \mathrm{~cm}$. long or less, rounded or retuse at the apex, rounded or obtuse at the base, obsoletely veined and glabrous above when old, densely whitishtomentulose and with pinnate venation beneath, the short stout petioles I-2 $\mathrm{mm}$. long; flowers solitary in the upper axils; peduncles slender, puberulent, $2-4 \mathrm{~cm}$. long; calyx-lobes elliptic to ovate, $4 \mathrm{~mm}$. long, $3 \mathrm{~mm}$. broad, tomentose; petals oval, $6 \mathrm{~mm}$. long, $4.5 \mathrm{~mm}$. broad.

Dry rocky soil, serpentine hills near mouth of the Rio Yamaniguey, Oriente (Shafer 4278).

Psidium saxicola Britton \& Wilson, sp. nov.

A shrub, I m. high, with terete, nearly erect, densely shortpubescent branches. Leaves ovate or elliptic-ovate, subcoriaceous, very nearly sessile, densely copiously punctate, acute or obtuse at the apex, subcordate or rounded at the base, glabrous and indistinctly veined above, pubescent on the rather prominent veins beneath, the midvein impressed above, elevated on the underside; flowers solitary in the axils; peduncles short-pubescent, 2-6 cm. long; bractlets 2, subfoliaceous, ovate-oblong, pubescent, 4-7 $\mathrm{mm}$. long; ovary pubescent; calyx-lobes tomentose, elliptic-ovate to oval, $3.5 \mathrm{~mm}$. long, $3 \mathrm{~mm}$. broad, ciliate; petals broadly obovate to suborbicular, $8.5-9 \mathrm{~mm}$. long, $6.5-7 \mathrm{~mm}$. broad; young fruit oblong, pubescent, $9 \mathrm{~mm}$. long.

Rocky coastal hills, Santiago Bay. Oriente. Type from E1 Morro (Britton \& Cowell 12544). 
Calyptranthes Clementis Britton \& Wilson, sp. nov.

A shrub, 2-3 m. high; young twigs terete, densely brown-pilose, the older ones glabrous. Leaves subcoriaceous, elliptic-lanceolate, $5-8 \mathrm{~cm}$. long, $3 \mathrm{~cm}$. wide or less, rather distinctly pinnately veined with the midvein slightly impressed above and prominent beneath, the upper surface glabrous, dull green, the under surface pale, densely pilose when young, glabrous when old, the apex long-acuminate, the base rounded or obtuse, the stout petioles 2-4 mm. long; peduncles 0.6-1.8 cm. long, pilose with brownish hairs; heads densely bracted, the bracts brown-pilose, the outer bracts lanceolate, 6-7.5 mm. long, $2.8-3 \mathrm{~mm}$. broad, pinnatelyveined, the inner ones smaller; hypanthium densely brown-pilose ; fruit (immature) subglobose, $7 \mathrm{~mm}$. in diameter, tuberculate, sparingly pilose.

Loma de Ponciano, Sancti Spiritus mountains, Santa Clara, about $750 \mathrm{~m}$. altitude (Léon \& Clement 6680).

Calyptranthes Caroli Britton \& Wilson, sp. nov.

A shrub, about $3 \mathrm{~m}$. high, the young twigs terete, loosely brown-pilose with spreading hairs, glabrous in age. Leaves subcoriaceous, narrowly elongate-lanceolate, 5-9.5 cm. long, I.4-I.8 $\mathrm{cm}$. wide, finely pinnately-veined above, reticulate-veined beneath, the midvein not or slightly elevated above, prominent beneath, the upper and lower leaf-surfaces brown-pilose when young, glabrous in age, the apex long-acuminate, the base rounded; petioles 5-7 mm. long, channelled above, pilose; heads manyflowered, sessile or nearly so, few-bracted, the bracts lanceolate, 8-9 mm. long, $3 \mathrm{~mm}$. broad, keeled on the back, loosely pilose; hypanthium densely brown-pilose; fruit unknown.

Banks of Arroyo Ahoga Caballos between Catalina and Caimito, Pinar del Rio, roo-I 50 m. altitude (Léon \& Charles 4895).

Calyptranthes clarensis Britton \& Wilson, sp. nov.

A shrub or small tree, up to $3 \mathrm{~m}$. high or a little higher; young twigs subterete, pilose with short, mostly appressed hairs, glabrous in age. Leaves subcoriaceous, elliptic-lanceolate or elliptic-oblanceolate, $2-4 \mathrm{~cm}$. long, 7-I4 $\mathrm{mm}$. wide, rather indistinctly pinnately veined on both surfaces, the midvein impressed above, prominent beneath, the upper surface glabrous or nearly so, the lower surface appressed-pilose when young, glabrous or nearly so in age, acuminate at the apex, cuneate at the base; petioles 2-2.5 mm. long; inflorescence I-3-flowered; peduncles 2-2.5 $\mathrm{cm}$. long, slender, puberulent with appressed hairs when young, 
glabrous or nearly so in age; hypanthium appressed brownpilose; fruit unknown.

Sierra del Caballete, Sancti Spiritus mountains, Santa Clara, at 800-850 m. altitude (Léon \& Clement 6540).

Eugenia Cowellii Britton \& Wilson, sp. nov.

A shrub, I-2 m. high, the slender gray twigs puberulent when young, soon glabrous. Leaves oblong to orbicular-elliptic, coriaceous, very small, only 4-7 mm. long, rounded at both ends, tuberculate and veinless above, black-punctate and with the midvein rather prominent beneath, the petioles about I $\mathrm{mm}$. long; fruit subglobose or ellipsoid, red, about $9 \mathrm{~mm}$. long.

Coastal rocks, southern Oriente. Type collected at Cabañas Bay (Britton \& Cowell I27I6).

Eugenia (?) cabanasensis Britton \& Wilson, sp. nov.

A tree $6 \mathrm{~m}$. high, the numerous slender twigs gray, glabrous. Leaves oblong-obovate, coriaceous, light green, $8-\mathrm{I} 5 \mathrm{~mm}$. long, 4-6 mm. wide, rounded at the apex, narrowed or cuneate at the base, smooth, shining and with the midvein impressed above, dull, copiously tuberculate-punctate and with the midvein rather prominent beneath, the internal venation wholly obscure, the petioles about I mm. long; flowers and fruit unknown.

Rocky hillside, Cabañas Bay, southern Oriente (Britton \& Cowell I2820).

Eugeina moensis Britton \& Wilson, sp. nov.

A shrub or a slender tree up to $5 \mathrm{~m}$. high, glabrous throughout, the slender twigs densely leafy. Leaves narrowly oblong or linear-oblong, $2.5-4 \mathrm{~cm}$. long, 6-10 $\mathrm{mm}$. wide, rounded or obtuse at the apex, narrowed at the base, tuberculate-punctate on both sides, the midvein lightly impressed above, faint beneath, the lateral venation almost wholly obscure, the rather stout petioles 4-7 $\mathrm{mm}$. long; flowers axillary, solitary, on filiform peduncles about $2 \mathrm{~cm}$. long; calyx about $2.5 \mathrm{~mm}$. long, its lobes ovate; young fruit narrowly oblong, $6 \mathrm{~mm}$. long.

Rocky banks of mountain stream, Camp La Gloria, south of Sierra Moa (Shafer 8I00).

A shrub with similar foliage, but with the leaves nearly smooth on both sides and the midvein prominent beneath, growing along a rocky river near Camp San Benito, Oriente, at 900 meters elevation, may be a related species. 
Eugenia havanensis Britton \& Wilson, sp. nov.

A shrub about $2 \mathrm{~m}$. high, the young twigs glabrous or slightly puberulent. Leaves obovate to elliptic or oval, $2.5-3.8 \mathrm{~cm}$. long,

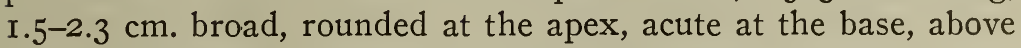
rather light green, lustrous and finely tuberculate-glandular when young, dark green and smooth or nearly so in age, beneath glabrous, paler and finely tuberculate-glandular, the midrib prominent; flowers axillary, solitary; pedicels slender, $\mathrm{I}-3 \mathrm{~cm}$. long, glabrous or slightly pubescent; calyx-tube about $3 \mathrm{~mm}$. long, puberulent with appressed whitish hairs, its lobes unequal, roundedovate to suborbicular, ciliolate; petals obovate, $8 \mathrm{~mm}$. long, 5-5.5 $\mathrm{mm}$. broad, ciliolate.

On hills, Havana. Type collected at Cuabal north of Minas (Léon \& Roca 6212). Possibly a species of Psidium.

Eugenia varia Britton \& Wilson, sp. nov.

A low shrub, only about $2 \mathrm{dm}$. high, some of the branches decumbent and radicant; young twigs puberulent, the older ones gray and glabrous. Leaves chartaceous, various in form, ovate to elliptic or suborbicular, $2 \mathrm{~cm}$. long or less, acute, obtuse or rounded at the apex, mostly rounded at the base, distinctly pinnately veined, the upper surface tuberculate, the petioles I-I.5 $\mathrm{mm}$. long; flowers few or solitary, mostly in the upper axils; pedicels puberulent, $3 \mathrm{~mm}$. long or less; calyx I-I.2 mm. long, sparingly pubescent, its lobes rounded-ovate to ovate, obtuse or acutish at the apex, ciliate; petals oval to suborbicular, I.8-2 $\mathrm{mm}$. long, I.7-2 mm. broad, rounded at the apex; fruit subglobose, 5 $\mathrm{mm}$. long.

Banks, Pinar del Rio. Type collected between San Diego and La Palma (Léon 5I58).

Eugenia (?) Earlei Britton \& Wilson, sp. nov.

A shrub about $2 \mathrm{~m}$. high, with short terete glabrous twigs. Leaves elliptic or ovate-elliptic, chartaceous, $2.5-4 \mathrm{~cm}$. long, 3 $\mathrm{cm}$. wide or less, distinctly pinnately veined, obtuse, rounded or bluntly acute at the apex, obtuse at the base, bright green, shining, somewhat tuberculate above and with impressed midvein, pale green, dull and with midvein prominent beneath, the stout petioles about I mm. long.

Valley near Guanabana, Trinidad Mountains, Santa Clara, $260 \mathrm{~m}$. altitude (Britton, Earle \& Wilson, 477I). 
Eugenia Rocana Britton \& Wilson, sp. nov.

A shrub, about $2 \mathrm{~m}$. high, the slender young twigs puberulent, the older ones gray, terete, glabrous. Leaves oblong or oblonglanceolate, subcoriaceous, $2.5 \mathrm{~cm}$. long or less, acute at the apex, obtuse at the base, the midvein impressed above, prominent beneath, the lateral venation delicate, not prominent, the upper surface tuberculate, the puberulent petioles about I mm. long; flowers solitary or few together and nearly sessile; calyx I. $5 \mathrm{~mm}$. long, densely whitish-pubescent with appressed hairs, its lobes triangular to triangular-ovate, $2-2.5 \mathrm{~mm}$. long, acuminate.

Rocky summit of Sierra de Anafe, Havana (Léon \& Roca $7 I 42)$.

Eugenia clarensis Britton \& Wilson, sp. nov.

A tree about $6 \mathrm{~m}$. high, the slender young twigs puberulent. Leaves oblong or oblong-oblanceolate, subcoriaceous, $2.8 \mathrm{~cm}$. long or less, 6-1o mm. wide, acute at the apex, mostly obtuse at the base, the midvein impressed above, prominent beneath, the lateral venation wholly obscure, the upper surface tuberculate, the stout petioles about $1.5 \mathrm{~mm}$. long; flowers axillary, solitary or in 2-4flowered clusters; pedicels 2-4 $\mathrm{mm}$. long, pubescent; bractlets lanceolate; calyx-tube whitish-pubescent with long hairs, $2 \mathrm{~mm}$. long, its lobes ovate, acuminate at the apex, ciliate; petals oval, 5 $\mathrm{mm}$. long, $3 \mathrm{~mm}$. broad, rounded at the apex.

Woods, Pitajones, Santa Clara (Shafer I2275).

Eugenia anafensis Britton \& Wilson, sp. nov.

A shrub about $2 \mathrm{~m}$. high, the young twigs slender, densely puberulent. Leaves oblong or oblong-lanceolate, chartaceous, glabrous, $3-5 \mathrm{~cm}$. long, 9-18 $\mathrm{mm}$. wide, acute or short-acuminate at the apex, obtuse or narrowed at the base, the midvein impressed above, prominent beneath, the lateral venation delicate, not prominent, the upper surface tuberculate; flowers solitary and very nearly sessile in the axils; fruit subglobose, about $8 \mathrm{~mm}$. in diameter, the persistent calyx-lobes triangular to triangularovate, $2.5 \mathrm{~mm}$. long, acute.

Rocky hillside, Sierra de Anafe, Pinar del Rio (Wilson II 587).

Eugenia ignota Britton \& Wilson, sp. nov.

A shrub about $3 \mathrm{~m}$. high, the young twigs, inflorescence and veins of the young leaves appressed-pubescent. Leaves oblong to elliptic, thin-chartaceous, $3 \mathrm{~cm}$. long or less, $8-16 \mathrm{~mm}$. wide, 
acute at the apex, narrowed or obtuse at the base, rather distinctly pinnately veined, smooth and glabrous above, punctate and with some scattered hairs beneath, the midvein impressed in the upper surface, prominent on the lower, the puberulent petioles I-2 $\mathrm{mm}$. long; flowers few, in small bracteolate axillary clusters ; pedicels 2-3,5 $\mathrm{mm}$. long; calyx about $1.5 \mathrm{~mm}$. long, pubescent with scattered, appressed hairs, its lobes rounded-ovate, acute or short-acuminate.

Coastal plain, San Juan, Isle of Pines (Britton \& Wilson I5455).

Eugenia Bakeri Britton \& Wilson, sp. nov.

Young twigs puberulent, slender, terete, soon becoming glabrous. Leaves oblong to oblong-lanceolate, coriaceous, $2-3.5 \mathrm{~cm}$. long, acute or short-acuminate at the apex, narrowed at the base, shining, copiously impressed-punctate with impressed midvein but otherwise nerveless above, dull, pinnately veined and with midvein prominent beneath, the stout petioles about I mm. long; flowers solitary or 2 or 3 together in the axils, sessile; calyx 2 $\mathrm{mm}$. long, more or less loosely pubescent with brownish hairs, its lobes rounded-ovate to oval, obtuse or rounded at the apex.

Santa Catalina, Pinar del Rio (Baker 969).

A barren specimen with similar foliage but with leaves rounded at base, from Rio Guao, Pinar del Rio (Britton \& Cowell IOIO2), may represent this species or a related one.

\section{Family MELASTOMACEAE}

Tamonea (?) moensis Britton, sp. nov.

A glabrous shrub or small tree. Leaves coriaceous, elliptic or ovate-elliptic, acute or acuminate at the apex, narrowed at the base, entire, 4.5-7 cm. long, 3-nerved, the 2 lateral veins arising just above the base, the veins impressed above, prominent beneath, the secondary venation delicate, the rather stout petioles 6-9 mm. long; panicle loosely few-flowered; pedicels slender, IO-I $4 \mathrm{~mm}$. long; fruit globose, glabrous, about $7 \mathrm{~mm}$. in diameter, the persistent calyx-limb truncate.

Camp La Gloria, south of Sierra Moa, Oriente (Shafer 8073, type; 8038).

Calycogonium saxicola Britton \& Wilson, sp. nov.

A low shrub, about $6 \mathrm{dm}$. high, the young twigs, petioles and leaf-blades finely scurfy. Leaves subcoriaceous, bright green, 
shining, ovate to elliptic, $\mathrm{I}-2.5 \mathrm{~cm}$. long, acute or acuminate at the apex, mostly narrowed at the base, 3 -nerved, the lateral veins arising just above the base, the secondary venation indistinct, glabrous on both sides when old, except for a tuft of short hairs in the axils of the lateral veins; flowers 5-parted, solitary or 2 together at the end of a peduncle, I-I.5 cm. long; pedicels filiform, 5-IO $\mathrm{mm}$. long; calyx-tube terete, subcampanulate, $5 \mathrm{~mm}$. long, its 5 subulate teeth $2-2.5 \mathrm{~mm}$. long; anthers a little shorter than the filaments; petals white, obovate, obtuse, $7-8 \mathrm{~mm}$. long; fruit black, subglobose, about $6 \mathrm{~mm}$. in diameter.

Rocks, vicinity of Sumidero, Pinar del Rio. Type from Sierra Caliente (Shafer I3770).

Pachyanthus Clementis P. Wilson, sp. nov.

A shrub with densely ferruginous twigs and branches. Leaves ovate-lanceolate, 9-12 cm. long, $3.5-4.5 \mathrm{~cm}$. broad, glabrous or nearly so above, pubescent beneath with stellate hairs, cordate at the base, acuminate at the apex, coriaceous, petioled, 3-5-nerved, the veins and lateral nerves prominent beneath, slightly impressed above; inflorescence peduncled; calyx urnshaped, 7-8 $\mathrm{mm}$. long, 4-5 $\mathrm{mm}$. broad, densely pubescent with rather long shaggy hairs, the lobes long-acuminate.

Loma Los Helechales, Banao Mountains, Santa Clara (Léon \& Clement 5399).

Pachyanthus mantuensis Britton \& Wilson, sp. nov.

A shrub I $\mathrm{m}$. high or less, the branches, twigs and calyx densely scurfy with brownish stellate scales. Leaves $4-8 \mathrm{~cm}$. long, $2-3.6 \mathrm{~cm}$. broad, elliptic to elliptic-ovate, obtuse at the apex, rounded and subcordate at the base, yellowish green, punctate and glabrous or nearly so above, slightly paler and scurfy especially on the veins beneath, coriaceous; pedicels I-I.5 cm. long; calyx urn-shaped, the lobes with a short keel on the back near the apex; petals ovate-oval to oval, I2 $\mathrm{mm}$. long, 7-8 $\mathrm{mm}$. broad, rounded at the apex, puberulent.

Dry prairie land, between Guane and Mantua, Pinar del Rio (Shafer II229).

Ossaea Shaferi Britton \& Wilson, sp. nov.

A shrub I-2 m. high, with densely hirsute twigs, leaves and inflorescence. Leaves ovate to ovate-lanceolate, $4-9 \mathrm{~cm}$. long, 5 -nerved, acute or acuminate at the apex, rounded or obtuse at the base, the upper surface densely and finely tuberculate, each 
tubercle bearing a stiff bristly hair; veins of the under leafsurface strong and elevated, two of the lateral ones arising from near the base, the other two arising from above the base; petioles stout, $2 \mathrm{~cm}$. long or less ; flowers $2-4$, sessile at the end of a short stout peduncle, or some of them solitary; calyx densely hirsute, its 5 lobes subulate, long-ciliate, about $3 \mathrm{~mm}$. long; fruit densely hirsute.

Thickets, mountains of northern Oriente. Type from Camp La Gloria, south of Sierra Moa (Shafer 8I52).

Ossaea navasensis Britton \& Wilson, sp. nov.

A shrub about $2 \mathrm{~m}$. high, with reddish or reddish-brown scurfy twigs and petioles. Leaves lanceolate-ovate to ovate, 3-5 $\mathrm{cm}$. long, I.3-2 cm. broad, 3-nerved, acuminate at the apex, acute at the base, glabrous and dull above, the primary veins impressed, paler beneath, the primary veins rather prominent; petioles $5^{-1}$ I $\mathrm{mm}$. long, ciliate; flowers axillary, solitary or few, sessile; calyxlobes 4, linear-lanceolate, long-ciliate; petals acute.

Dense woods, trail, Navas to Camp Buena Vista, Oriente (Shafer 4449).

Ossaea nipensis Britton \& Wilson, sp. nov.

A shrub I $\mathrm{m}$. high, with brownish or reddish-brown scurfy twigs and petioles. Leaves ovate, I.5-3 cm. long, 7-1 $8 \mathrm{~mm}$. broad, 3-nerved, acute to short-acuminate at the apex, the tip obtuse, rounded or somewhat acutish at the base, dark green, and glabrous above, the primary veins impressed, brown and somewhat scurfy beneath, the veins rather prominently elevated; petioles 4-6 mm. long, slender; flowers solitary or few, subsessile; calyx-lobes 4, minute, broadly triangular, acute; petals oblongelliptic, $1.5 \mathrm{~mm}$. long, $0.8 \mathrm{~mm}$. broad, acute; young fruit subglobose, $2 \mathrm{~mm}$. in diameter.

Rich woods, Sierra Nipe, near Woodfred, Oriente (Shafer 3439).

\section{Family ERICACEAE}

Kalmiella simulata Britton \& Wilson, sp. nov.

A shrub 6-9 dm. tall, with glabrous foliage and puberulent branches; leaves thick, lanceolate-subulate on account of the strongly revolute margins, 5-6 $\mathrm{mm}$. long, I-I.5 $\mathrm{mm}$. broad, bright green and shining above, paler beneath, sessile; pedicels longer than the leaves, sparsely glandular-pilose; sepals lanceolate, 5 
$\mathrm{mm}$. long, obtuse or acutish, glabrous ; corolla pinkish-white, I2-I3 $\mathrm{mm}$. broad; filaments pubescent near the base; capsule immature.

White sandy places, vicinity of Los Indios, Isle of Pines (Britton \& Wilson I4205).

\section{Family APOCYNACEAE}

Rauwolfia linearifolia Britton \& Wilson, sp. nov.

A glabrous shrub $4.5 \mathrm{dm}$. high, with slender grayish branches. Leaves in whorls of 3 's, linear, 4-6.5 cm. long, 3-4 mm. wide, dark green above, paler beneath, the midvein prominent on both surfaces, the lateral veins indistinct; calyx-lobes lanceolate, I-I.5 $\mathrm{mm}$. long, acute to acuminate; corolla purplish, its tube slender, 7-9 $\mathrm{mm}$. long, the lobes elliptic, $4 \mathrm{~mm}$. long, r. $3 \mathrm{~mm}$. wide; ovary immersed in a cup-shaped disk ; style filiform; carpels two, united at the base, one carpel sometimes abortive.

Type collected on limestone hill, Paso Estancia to the Pinales, Oriente (Shafer I754).

Echites minima Britton \& Wilson, sp. nov.

Stems slender, twining, puberulent. Leaves oblong, $I-2 \mathrm{~cm}$. long, 4-5 $\mathrm{mm}$. broad, acuminate at the apex, rounded and cordate at the base, glabrous, short-petioled, the midvein indistinct above, prominent beneath ; calyx-lobes elliptic-lanceolate to elliptic, 2-2.5 $\mathrm{mm}$. long, I-I.I mm. broad, acuminate at the apex; corolla-tube 3-3.5 mm. long, the lobes suborbicular, light yellow, $3.5 \mathrm{~mm}$. long, $4 \mathrm{~mm}$. broad.

In dry grassy places, barren savannas southeast of Holguin, Oriente (Shafer 2955).

An incomplete specimen from savannas between Queen City and Minas, Camaguey (Shafer 2928), is referred to this species with doubt.

\section{Family CONVOLVULACEAE}

Exogonium incertum Britton, sp. nov.

Vine, slender, glabrous up to $8 \mathrm{dm}$. long or longer. Leaves unknown; corymbs few-several-flowered, short-peduncled; pedicels 5-12 mm. long; sepals about $6 \mathrm{~mm}$. long, elliptic-ovate, obtuse or rounded; corolla tubular-funnelform, glabrous, pink with a purple throat, $3-4 \mathrm{~cm}$. long, its tube very narrow within the calyx, gradually enlarged above, its limb about $1.5 \mathrm{~cm}$. broad; capsule 
ovoid-globose, $8 \mathrm{~mm}$. long; seeds oblong, with long brown hairs.

Hillsides, northwestern Oriente. Type from Loma Pilon, in eruptive mountains near Holguin (Shafer I235).

\section{Family HYDROPHYLLACEAE}

Nama cubana $P$. Wilson, sp. nov.

A spiny shrub $2-3.5 \mathrm{dm}$. tall, with puberulent twigs. Leaves obovate or somewhat obovate-spatulate, $1-2.5 \mathrm{~cm}$. long, 3-6 mm. broad, glabrous or nearly so, rounded or acutish at the apex, cuneate at the base, short-petioled; sepals ovate, 5-7 mm. long, $3.5-5 \mathrm{~mm}$. broad, acute or rounded at the apex, glabrous; capsule subglobose, 3-3.5 mm. long, glabrous; styles mostly 3, shorter than the sepals.

In mud, Columbia, Camaguey (Shafer 6I9).

\section{Family CORDIACEAE}

Varronia Shaferi Britton, sp. nov.

Shrub-like, branched, the twigs, petioles and peduncles appressed-pubescent, scabrous. Leaves oblong or oblong-lanceolate, coriaceous, entire, $8 \mathrm{~cm}$. long or less, $2-4 \mathrm{~cm}$. wide, acute or acuminate at the apex, narrowed and acute at the base, shining and glabrous or nearly so above, short-pubescent beneath, the veins impressed above, prominent beneath, the rather stout petioles I-2 cm. long; peduncles terminal, rather stout, $5-8 \mathrm{~cm}$. long; flowers densely short-spicate; spikes $1.5-3 \mathrm{~cm}$. long, about I cm. thick; calyx strigose, about $6 \mathrm{~mm}$. long, its triangular lobes tapering into a linear, caudate tip ; corolla $3.5-4 \mathrm{~mm}$. long, white, a little longer than the calyx-tube, its lobes short, rounded; fruit oval, about $7 \mathrm{~mm}$. long.

Moist woods between Navas and Camp Buena Vista, Oriente, at 650 meters altitude (Shafer 4448).

Bourreria Taylori Britton, sp. nov.

A tree, 5-8 m. high, the young twigs and inflorescence loosely pilose. Leaves spatulate-oblanceolate, subcoriaceous, $3-7 \mathrm{~cm}$. long, $2 \mathrm{~cm}$. wide or less, obtuse or rounded at the apex, cuneate at the base, smooth, glabrous and reticulate-veined above, sparingly pilose beneath, the petioles $2-4 \mathrm{~mm}$. long; inflorescence paniculate, several-flowered; calyx oblong-campanulate, densely pilose, about $6 \mathrm{~mm}$. long, its teeth triangular, acute; styles united to above the middle, stout ; fruit orange-red, globose, about $8 \mathrm{~mm}$. in diameter. 
Sevilla Estate, near Santiago, Oriente, at $260 \mathrm{~m}$. elevation (Taylor 43I).

Rochefortia stellata Britton \& Wilson, sp. nov.

A tree, $5 \mathrm{~m}$. high, with grayish, flexuose branches and puberulent spiny twigs. Leaves elliptic, subcoriaceous, brittle, 1.5-2.8 $\mathrm{cm}$. long, I.2-1.8 cm. wide, rounded and occasionally slightly emarginate at the apex, rounded at the base, short-petioled, lustrous and glabrous or with few scattered stellate hairs above, densely puberulent beneath with grayish, stellate hairs; flowers solitary or several, axillary, short-pedicelled; calyx densely stellate-tomentulose, the lobes triangular-ovate; corolla-tube short, the lobes elliptic-ovate to elliptic, $4 \mathrm{~mm}$. long, $2.5 \mathrm{~mm}$. wide, ciliolate; ovary glabrous, the styles separate to near the base, pubescent ; young fruit subglobose, $6 \mathrm{~mm}$. in diameter, glabrous.

Coastal thicket, Ensenada Cabanita, Oriente (Britton \& Cowell I2634).

Rochefortia cubensis Britton \& Wilson, sp. nov.

A shrub with brownish-gray, puberulent, spiny twigs. Leaves elliptic, chartaceous, 6-9 $\mathrm{mm}$. long, 3-6 mm. wide, rounded at both ends, the base occasionally somewhat inequilateral, pubescent above with simple, scattered, appressed hairs, glabrous or nearly so beneath, short-petioled; calyx-lobes ovate, ciliate, 2.5 $\mathrm{mm}$. long; fruit subglobose, $4.5 \mathrm{~mm}$. in diameter, yellowish-red.

Thicket east of Playa de Marianao (Léon 7228).

\section{Family VERBENACEAE}

Duranta arida Britton \& Wilson, sp. nov.

A strict shrub, $\mathrm{I}-3 \mathrm{~m}$. high, the slender twigs and branches of the inflorescence puberulent. Leaves obovate to elliptic or oval, $0.6-1.5 \mathrm{~cm}$. long, $0.5-0.9 \mathrm{~cm}$. wide, acute or rounded at the apex, cuneate or obtuse at the base, entire or minutely and sparingly denticulate above the middle, dark green, glabrous and inconspicuously veined above, paler and glabrous beneath, the lateral veins three or four on each side of the midvein; petioles I-2 $\mathrm{mm}$. long, slender; fruit subglobose, $5 \mathrm{~mm}$. in diameter, on pedicels I mm. long.

Thickets, Sabana to Maisi, Oriente (Shafer 7904, type; 79II).

Callicarpa Shaferi Britton \& Wilson, sp. nov.

A shrub up to $3.3 \mathrm{~m}$. high, the twigs, petioles, under leafsurfaces and inflorescence densely white stellate-scurfy. Leaves 
oblong, oblong-lanceolate or oblong-oblanceolate, chartaceous, 3-8 $\mathrm{cm}$. long, I-3 cm. wide, entire or very nearly so, acute, obtuse or rounded at the apex, obtuse, subtruncate or narrowed at the base, dark green, finely reticulate-veined and glabrous above, strongly reticulate-veined beneath, the slender petioles 5-12 $\mathrm{mm}$. long; cymes small, peduncled, much shorter than the leaves; pedicels very short; calyx obconic, white stellate-scurfy, $\mathrm{I} .5 \mathrm{~mm}$. wide, the lobes very short, broadly triangular; corolla pink, 3-3.5 mm. long, the lobes oval, rounded at the apex; filaments filiform, exserted; fruit subglobose, scurfy, blue, $3.5-4 \mathrm{~mm}$. in diameter.

Limestone hills and plains, Pinar del Rio and Isle of Pines. Type from limestone hills, vicinity of Sumidero, Pinar del Rio (Shafer 13526).

Callicarpa Wrightii Britton \& Wilson, sp. nov.

A shrub, 6-12 dm. high, the twigs, petioles and inflorescence densely brown stellate-scurfy. Leaves obovate to elliptic or oblong, membranous, 7-12 cm. long, $1.5-5 \mathrm{~cm}$. wide, crenateserrate at least above the middle, acuminate at the apex, cuneate at the base, dark green, glabrous and inconspicuously veined above, green, sparingly stellate on the principal veins, lightly reticulate-veined and copiously resinous-dotted beneath, the petioles 5-9 mm. long; cymes few-flowered, short-peduncled, much shorter than the leaves, sometimes not longer than the petioles; fruit greenish, about $5 \mathrm{~mm}$. in diameter, on pedicels about I.5 $\mathrm{mm}$. long.

Valleys and hillsides, northern Oriente. Type from Moa Bay, east of Rio Moa (Shafer $8308 \mathrm{~A}$ ).

Callicarpa cuneifolia Britton \& Wilson, sp. nov.

A shrub up to $2 \mathrm{~m}$. high, the twigs, petioles, under leafsurfaces and branches of the inflorescence densely stellatepubescent with ferruginous hairs. Leaves obovate or elliptic, chartaceous, 4-7 cm. long, $1.5-3 \mathrm{~cm}$. wide, crenulate, acute or acuminate at the apex, cuneate at the base, dark-green and somewhat scabrous above, the midvein strongly impressed, reticulateveined and finely glandular beneath, the petioles about $6 \mathrm{~mm}$. long; cymes small, peduncled, shorter than the leaves; pedicels I.5-2 $\mathrm{mm}$. long; calyx $3 \mathrm{~mm}$. broad; fruit subglobose, $4 \mathrm{~mm}$. in diameter, puberulent when young, glandular.

Hillsides and pine woods, northern Oriente. Type from a dry serpentine hill, Loma Santa Teresa, near El Yunque (Shafer $774 I)$. 
Callicarpa nipensis Britton \& Wilson, sp. nov.

A shrub about $6 \mathrm{dm}$. high, the twigs, inflorescence, petioles and under leaf-surfaces densely brown stellate-tomentose. Leaves linear-oblong, coriaceous, entire or very slightly repand, $12 \mathrm{~cm}$. long or less, 8-18 $\mathrm{mm}$. wide, acute at the apex, narrowed at the base, tapering gradually from near the middle to both ends, dark green and minutely setulose with impressed venation above, strongly elevated-veined beneath, the rather stout petioles 6-9 $\mathrm{mm}$. long; cymes peduncled, shorter than the leaves, severalflowered; fruit blue, compressed, short-pubescent, about $7 \mathrm{~mm}$. broad.

Border of pinelands, Sierra Nipe, near Woodfred, Oriente, 450-550 meters altitude (Shafer 3026).

Vitex Clementis Britton \& Wilson, sp. nov.

Young twigs rather slender, densely tomentulose. Leaves 3-foliolate; petioles slender, tomentulose, $2-7 \mathrm{~cm}$. long; petiolules $2 \mathrm{~cm}$. long or less; leaflets oblong-elliptic, 6-1o $\mathrm{cm}$. long, rather thin, acute or obtuse at the apex, narrowed at the base, glabrous above, or nearly so, except upon the impressed veins, densely tomentulose and with elevated veins beneath; cymes several or numerous, panicled, few-several-flowered, tomentulose; pedicels 2-5 mm. long; calyx short-campanulate, about $6 \mathrm{~mm}$. broad, its lobes suborbicular, ciliate; corolla purple, $\mathrm{I} .5-\mathrm{r} .7 \mathrm{~cm}$. broad, villous on the outside, its lobes very unequal, its tube $6 \mathrm{~mm}$. long.

Coastal thickets, Santiago, Oriente (Clement I68, type) ; collected also at Cabo Cruz, as shown by a specimen from the Sauvalle Herbarium.

\section{Pseudocarpidium Shaferi Britton, sp. nov.}

A shrub or small tree up to $4 \mathrm{~m}$. high, the young twigs, petioles and under leaf-surfaces whitish-tomentulose. Leaves oblong, or oblong-oblanceolate, coriaceous, $3.5 \mathrm{~cm}$. long or less, 6-1o $\mathrm{mm}$. wide, entire, or rarely with I or 2 spinulose teeth, acute and spinulose-tipped, the base subcuneate, the principal veins delicate above, rather prominent beneath, the upper surface dark green, glabrous, densely and finely reticulate-veined; panicle slender, puberulent, a little longer than the leaves; calyx $2 \mathrm{~mm}$. long, its ovate, sharply acute lobes somewhat shorter than the tube; corolla puberulent, about $5 \mathrm{~mm}$. long; fruit densely pubescent, 4-lobed, depressed, 4-6 mm. broad.

Coastal thickets between Sabana and Maisi, Oriente (Shafer 7901 ). 
Clerodendrum anafense Britton \& Wilson, sp. nov.

A tree up to Io $\mathrm{m}$. high, the twigs and petioles very minutely and sparsely hispidulous. Leaves elliptic or somewhat ellipticobovate, $4-9 \mathrm{~cm}$. long, $2-4.5 \mathrm{~cm}$. wide, obtuse or acute at the apex, rounded or acutish at the base, light green and glabrous, or minutely and obscurely hispidulous on the mid-vein above, paler, coarsely reticulate-veined and glabrous beneath, entire, coriaceous, short-petioled; calyx campanulate, 3.5-4 mm. wide, subtruncate at the apex, glabrous; corolla $2-2.5 \mathrm{~cm}$. long, white, the lobes oblanceolate to obovate; filaments filiform, exserted; anthers narrowly ovate or elliptic.

Rocky hillsides, Sierra de Anafe, Pinar del Rio (Wilson \& Léon II466).

Clerodendrum camagueyense Britton \& Wilson, sp. nov.

A shrub I-I.2 m. high, the twigs and petioles tuberculate and minutely hispidulous with mostly appressed hairs. Leaves obovate or elliptic-obovate, 7-I I cm. long, $3.5-6 \mathrm{~cm}$. wide, dark green, lustrous and hispidulous on the veins above, the secondary veins inconspicuous, paler, coarsely reticulate-veined and minutely hispidulous on the veins beneath, the margin denticulate; petioles I cm. long; calyx narrowly campanulate, subtruncate at the apex, glabrous; corolla about $4 \mathrm{~cm}$. long, white, the lobes oblanceolate; stamens exserted.

Savanna south of Sierra Cubitas, Camaguey (Shafer 496).

\section{Family LAMIACEAE}

Salvia scabrata Britton \& Wilson, sp. nov.

A more or less straggling shrub, I-I.2 m. tall, with hispid twigs. Leaves obovate, $4-6 \mathrm{~cm}$. long, $1.5-2.2 \mathrm{~cm}$. broad, obtuse or acutish at the apex, cuneate at the base, dull and glabrous above, paler and conspicuously punctate beneath, crenulate-serrate; petioles about $7 \mathrm{~mm}$. long, hispid; racemes axillary, the verticels $3-5 \mathrm{~cm}$. apart, few-flowered; pedicels $5-6 \mathrm{~mm}$. long; calyx I I-I $2 \mathrm{~mm}$. long, its lobes ciliolate, acute; corolla red or scarlet, $2-2.5 \mathrm{~cm}$. long, tomentose.

Mountains of northern Oriente. Type from along a rocky river, near Camp San Benito, $900 \mathrm{~m}$. altitude (Shafer 4075).

Salvia cubensis Britton \& Wilson, sp. nov.

A more or less erect shrub, I-I.5 m. tall, with puberulent twigs. Leaves oblanceolate or lanceolate, $4-9 \mathrm{~cm}$. long, r.2-2.5 
$\mathrm{cm}$. broad, obtuse to acute or acuminate at the apex, cuneate at the base, dull and glabrous above, paler beneath, punctate and serrulate or nearly entire, short-petioled; racemes terminal, the verticels 5-I2 $\mathrm{mm}$. apart; pedicels $2-3 \mathrm{~mm}$. long, puberulent; calyx 5-7 mm. long, its lobes acuminate; ciliolate; corolla scarlet, I.8-2.2 cm. long, tomentose.

Rocky places, mountains of northern Oriente. Type from along shaded stream near base of Loma Mensura, about $680 \mathrm{~m}$. altitude (Shafer 3766).

\section{Hyptis Shaferi Britton, sp. nov.}

Creeping, rooting at the nodes, branched or simple, I m. long or less, sparingly and loosely pubescent or glabrate. Leaves ovate or orbicular-ovate, irregularly dentate, $2-5 \mathrm{~cm}$. long, acute or obtuse at the apex, narrowed or cuneate at the base, the petioles $2-8 \mathrm{~mm}$. long; heads peduncled, solitary in the axils, depressed-globose, densely many-flowered, $1.5-2.2 \mathrm{~cm}$. in diameter; peduncles slender, $\mathrm{I}-5 \mathrm{~cm}$. long; involucre-bracts oblong-lanceolate, acute or acutish, veiny, spreading, $6-8 \mathrm{~mm}$. long; calyx tubular, $7-8 \mathrm{~mm}$. long, its subulate ciliate teeth about one-half as long as the tube; corolla white or pinkish.

Grassy places, Pinar del Rio. Type from between Mantua and Arroyos (Shafer II248).

Hyptis rivularis Britton, sp. nov.

Erect, much branched, slender, but stiff, densely puberulent, I. $3 \mathrm{~m}$. high, the branches slender. Leaves of the stem not seen; leaves of the branches opposite, oblong-oblanceolate, IO-I $5 \mathrm{~mm}$. long, puberulent on both sides, few-dentate, acutish at the apex, cuneate at the base, the petioles I-2 $\mathrm{mm}$. long; flowers opposite or verticillate in the axils; fruiting pedicels about I mm. long, filiform; fruiting calyx densely puberulent, oblong, faintly veined, about $4 \mathrm{~mm}$. long, the lanceolate subulate teeth about one-half as long as the tube.

River bank, Trinidad, Santa Clara (Britton \& Wilson 5567).

\section{Family SOLANACEAE}

Physalis ignota Britton, sp. nov.

Annual; stem branched, often zigzag, angled and more or less densely villous with short hairs. Leaves ovate, 4-I $5 \mathrm{~cm}$. long, $3^{-10} \mathrm{~cm}$. wide, oblique and cuneate or somewhat rounded at the 
base, acute to acuminate at the apex, entire or somewhat repanddentate, puberulent at least on the veins, long-petioled; peduncles 5-7 mm. long, erect, in fruit 9-I2 mm. long, reflexed; calyx 3.5 $\mathrm{mm}$. long, densely short-villous, the lobes lanceolate, about as long as the tube; corolla campanulate, short-pilose, 5-5.6 $\mathrm{mm}$. wide, yellow, without a dark center; fruiting calyx ovoid, 3-4.5 $\mathrm{cm}$. long, $2.5-3 \mathrm{~cm}$. wide, angled.

Waste places and river banks, Camaguey, Santa Clara and Havana (type, Britton \& Wilson 5767); Guatemala.

Solanum moense Britton \& Wilson, sp. nov.

A straggling tree $3 \mathrm{~m}$. high, the slender twigs and branches armed with brownish prickles $2-2.5 \mathrm{~mm}$. long, hispid with ferruginous, stalked, stellate hairs. Leaves oblong to elliptic, 6-9 $\mathrm{cm}$. long, $2.2-3.5 \mathrm{~cm}$. broad, acute to acuminate at the apex, somewhat inequilateral and rounded at the base, entire with the margin more or less revolute, lustrous and with few slender brownish prickles above, the midvein and primary veins impressed, paler, dull and hispid beneath with stalked stellate hairs, the midvein and primary veins prominent; petioles $4-5 \mathrm{~mm}$. long; peduncles $3.5 \mathrm{~cm}$. long, stellate-hispid; fruiting calyx $2 \mathrm{~cm}$. wide; berries globose, $2.5 \mathrm{~cm}$. in diameter; seeds suborbicular, $4 \mathrm{~mm}$. long, 5 $\mathrm{mm}$. broad, flattened.

Thickets, Camp La Gloria, south of Sierra Moa, Oriente (Shafer 8125).

\section{Cestrum Wrightianum P. Wilson, sp. nov.}

A shrub about I $\mathrm{m}$. high, the branches conspicuously tomentose with branching star-like hairs. Leaves ovate, $5-8.5 \mathrm{~cm}$. long, $2.5-4.8 \mathrm{~cm}$. broad, short-acuminate at the apex, rounded and more or less subcordate at the base, sparingly tomentose on both surfaces when young with ferruginous star-like hairs; petioles 5-9 mm. long, tomentose; inflorescence shorter than the leaves; calyx cylindric, tomentose, its lobes triangular, about I mm. long; corolla $1.9-2.2 \mathrm{~cm}$. long, the tube rather slender, the lobes lanceolate, 5-6 mm. long, acuminate; filaments slender, pilose, adnate to a little above the middle of the corolla-tube; style slender; stigma subcapitate, included.

Cuba (C. Wright 386, herb. N. Y. Botanical Garden).

Cestrum Taylori Britton \& Wilson, sp. nov.

A glabrous tree, 5-8 m. high, with slender pale brown twigs. Leaves elliptic to somewhat elliptic-lanceolate, I3-I $5 \mathrm{~cm}$. long, 
$5-5.5 \mathrm{~cm}$. broad, acute at the apex, acutish or somewhat rounded at the base, glabrous and finely reticulate-veined on both surfaces; petioles I.3-1.6 cm. long; flowers solitary or several, axillary; calyx cylindric, about $\mathrm{I} \mathrm{cm}$. long, glabrous; corolla greenishyellow, $7-8 \mathrm{~cm}$. long, the tube slender, sparingly pilose within, especially near the base, the lanceolate lobes $1.2-1.5 \mathrm{~cm}$. long; filaments linear, adnate to the corolla-tube nearly to its throat; anthers elliptic to somewhat elliptic-ovate; style linear, $7-7.5 \mathrm{~cm}$. long, glabrous; stigma subcapitate.

Trail, Magdalena to Sierra Maestra, Oriente (Taylor 439).

Cestrum pinetorum Britton, sp. nov.

A glabrous shrub about I $\mathrm{m}$. tall, with slender brownish twigs. Leaves oblong-oblanceolate to obovate, or somewhat oblong-lanceolate, $4-6.5 \mathrm{~cm}$. long, $0.9-1.5 \mathrm{~cm}$. broad, obtuse or acutish at the apex, cuneate at the base, dark green and often obscurely veined above, paler and obscurely veined beneath, the petioles $2-5 \mathrm{~mm}$. long; panicles axillary or terminal; fruiting calyx campanulate, about $5 \mathrm{~mm}$. long, subsessile, its lobes triangular-ovate, $\mathrm{I}-\mathrm{I} .5 \mathrm{~mm}$. long; fruit obovoid to obovoid-ellipsoid, 6-7 mm. long, $5 \mathrm{~mm}$. broad, purplish-black.

Open pine woods, Sierra Nipe, near Woodfred, Oriente (Shafer 303I).

Brunfelsia Shaferi Britton \& Wilson, sp. nov.

A shrub $0.5^{-2} \mathrm{~m}$. tall, with glabrous or somewhat puberulent brownish twigs. Leaves oblong to elliptic-oblong, oblong-oblanceolate or oblong-obovate, $3-7.5 \mathrm{~cm}$. long, $0.8-1.5 \mathrm{~cm}$. broad, rounded or acutish at the apex, cuneate at the base, dark green, glabrous and indistinctly veined above, the midvein impressed, paler and glabrous beneath, the midvein prominent; petioles 2-5 $\mathrm{mm}$. long; calyx coriaceous, glabrous, the lobes oblong-ovate to ovate, about $3 \mathrm{~mm}$. long; berry subglobose, $\mathrm{I}-1.2 \mathrm{~cm}$. in diameter, sessile or subsessile, glabrous.

Plancha trail, Mensura to Woodfred, Oriente (Shafer 3870 ). Brunfelsia clarensis Britton \& Wilson, sp. nov.

A shrub I $\mathrm{m}$. or more high, with nearly glabrous twigs. Leaves obovate to broadly elliptic-obovate, 5-10 cm. long, 2.5-4.5 $\mathrm{cm}$. broad, rounded or acutish at the apex, acute at the base, glabrous or very minutely hispidulous above with scattered hairs, minutely hispidulous to glabrous beneath, the primary veins slender and rather indistinct; petioles $\mathrm{I}-\mathrm{I} .4 \mathrm{~cm}$. long; calyx coria- 
ceous, glabrous, the lobes ovate, $4 \mathrm{~mm}$. long; berry subglobose, about I $\mathrm{cm}$. in diameter, long-pedicelled.

Mordazo, Santa Clara (Léon \& Cazanas 5928).

\section{Family SCROPHULARIACEAE}

CHEILOPHYLLUM Pennell, gen. nov.

Stems extensively spreading, repent, much branched, fourangled, the angles narrowly winged, and with scattered, minute gland-tipped hairs. Leaves opposite, sessile, ovate, cuneate at base, slightly dentate, acutish, glandular-dotted, glabrous, the margin slightly recurved and thickened, $0.7-0.9 \mathrm{~cm}$. long. Pedicels 3-5 $\mathrm{mm}$. long, pubescent with gland-tipped hairs, not bracteolate. Sepals five, lance-linear, alike. Corolla $3 \mathrm{~mm}$. long, white, campanulate, the lobes about equaling the tube, the two posterior united throughout; the tube pubescent within on all sides. Filaments four, glabrous, the posterior pair slightly shorter; anthers glabrous. Style glabrous. Stigmas distinct. Capsule $2-2.5 \mathrm{~mm}$. long, ovate in outline, acute, glabrous, septicidal and loculicidal; the coalesced placentae thick, persisting, about one-half the length of the capsule. Seeds $2-3 \mathrm{~mm}$. long, short-oblong, ridged, minutely reticulate, brownish-black. [Name from $\chi \epsilon \iota \lambda o s$, margin, and $\phi v \lambda \lambda o v$, leaf.]

This monotypic genus is remote from Stemodia, which consists of erect herbs, with anther-sacs separated on arms of the connective and with longitudinally striate seeds. Its uniform sepals readily distinguish Cheilophyllum from the group of genera usually called Herpestis.

Cheilophyllum radicans (Griseb.) Pennell, comb. nov.

Stemodia radicans Griseb. Cat. P1. Cub. I82. 1866.

Palm barrens, Santa Clara, Havana; Jamaica.

\section{SILVINULA Pennell, gen. nov.}

Stems extensively spreading, repent, much branched, terete, strigose pubescent with ascending hairs. Leaves opposite, sessile, elliptic-oval, entire, obtuse, slightly pubescent on the margins and midrib, glandular-dotted, $0.8-1 \mathrm{~cm}$. long. Pedicels $\mathrm{I}-2 \mathrm{~mm}$. long, pubescent, at apex with two minute subulate bractlets. Sepals five, dissimilar; the three outer oblong-ovate, firm, conspicuously ridged, the two inner nearly linear, thin, obscurely veined. Co- 
rolla Io $\mathrm{mm}$. long, blue, nearly salverform, the lobes spreading, nearly orbicular, much shorter than the narrow tube, the two posterior united over $2 / 3$ length; glabrous throughout. Filaments four, glabrous, the posterior pair slightly shorter; anthers glabrous. Style glabrous. Stigmas distinct. Capsule $3 \mathrm{~mm}$. long, ellipsoid in outline, obtuse, glabrous, ridged, septicidal and loculicidal; the coalesced placentae and septum thin, persistent, platelike, extending the entire length of the capsule. Seeds $3^{-4} \mathrm{~mm}$. long, irregularly oblong, reticulate, yellowish-brown. [Named because of its resemblance to Silvia Benth., a Mexican genus.]

This monotypic genus is distinguished from all other segregates of Herpestis by the form of the corolla, and by the thick-walled, ridged capsule.

Silvinula humifusa (Griseb.) Pennell, comb. nov.

Herpestis humifusa Griseb. Cat. P1. Cub. I83. 1866.

Muddy borders of brooks and lagoons, Santa Clara, Pinar del Rio, Isle of Pines. Endemic.

\section{Caconapea stemodioides Pennell, sp. nov.}

Stem 3-4 dm. tall, obtusely four-angled, glabrous. Leaves 4-5 cm. long, $0.5-0.8 \mathrm{~cm}$. wide, narrowly lanceolate, serrate, longattenuate to the narrow but clasping base, glabrous, with many glandular dots. Pedicels one to three to an axil, I-I.5 mm. long, punctate with sessile glands. Bractlets two, filiform-subulate, I.5-2 $\mathrm{mm}$. long, placed immediately below calyx. Sepals: outermost $7 \mathrm{~mm}$. long, broadly ovate, rounded at base, two median nearly as long, narrower, somewhat one-sided, these three obtuse to acutish, rugosely reticulate-veined, green, glabrous, the two innermost lanceolate-linear, attenuate at apex, with evident midrib, broadly hyaline, obscurely ciliolate. Corolla 5-6 mm. long, posterior lobes united about $2 / 5$ length, pubescent within tube, especially on the anterior side, glabrous over bases of posterior lobes; "white." Filaments glabrous, the postero-lateral pair somewhat shorter, its anthers equaling those of the antero-lateral pair; posterior filament completely lost. Style glabrous, stigmas distinct. Capsule 3.5-4 mm. long, ovoid-oblong, punctate with sessile glands, dehiscing loculicidally and septicidally, the lateral portions of the septum adherent to the capsule-walls. Placentae rounded, protruding into the cells, coalescent with the persistent median part of the septum. Seeds $0.3 \mathrm{~mm}$. long, oblong-cylindric, truncate at each end, nearly black, longitudinally ridged and with obscure cross-reticulations. 
Type, river woods, vicinity of San Pedro, Isle of Pines, collected in flower and fruit, February 15-17, 1916 (Britton, Wilson \& Selby 14459).

Nearest to Caconapea decumbens (Fernald) Pennell, comb. nov. [Herpestis decumbens Fernald Proc. Am. Acad. 33: 91. 1897] of Mexico, which, however, has sepals reaching 8-9 $\mathrm{mm}$. long, obscurely reticulate (not rugose), corolla $8 \mathrm{~mm}$. long, anther-sacs over twice as large ( $0.8 \mathrm{~mm}$. long), and seeds nearlv as wide as long and with prominent cross-reticulations.

NAIADOTHRIX Pennell, gen. nov.

Stems submersed, long, much branched, glabrous or puberulent, terete. Leaves opposite, divided so as to appear whorled, and with ultimate filiform segments. Pedicels longer than the calyx, not bracteolate. Sepals five, alike or slightly unequal. Corolla blue, campanulate-personate, pubescent within on anterior side, the lobes about equaling the tube, the two posterior lobes united over one half length. Filaments four, glabrous, the posterior pair shorter. Anthers glabrous. A circle of bristles surrounding the base of the ovary. Style glabrous. Stigmas distinct. Capsule oblong, thin-walled, glabrous, septicidal and tardily loculicidal. Coalesced placentae and septum rather thick, little over one-half length of capsule. Seeds oblong, reticulate. [Name from Nacas, a water-nymph, and $\Theta \rho \iota \xi$, hair, in allusion to the finely divided leaves.]

Type species: Naiadothrix longipes Pennell.

Leaves, bristles surrounding ovary, and aquatic habit sharply distinguish Naiadothrix from all other segregates of Herpestis.

Naiadothrix longipes Pennell, sp. nov.

Stems, pedicels and calyx obscurely glandular-granulose. Leaves $2-2.5 \mathrm{~cm}$. long, three-branched from base, each branch and its pinnate segments filiform. Pedicels $35-50 \mathrm{~mm}$. long. Sepals nearly uniform, lanceolate-linear, $3 \mathrm{~mm}$. long. Corolla 6-7 mm. long, glabrous within, at. least the posterior lobes blue (the anterior probably yellowish). Capsule $2 \mathrm{~mm}$. long. Seeds $0.7-0.8 \mathrm{~mm}$. long, brown.

Type submerged in water, Laguna Jovero and vicinity, Pinar del Rio, collected in flower and fruit, December 5-7, I9I I (J.A. Shafer 10829).

Submerged in lagoons, Pinar de Rio and Isle of Pines. Endemic. 
Nearest to Naiadothrix reflexa (Benth.) Pennell, comb. nov. [Herpestis reflexa Benth. in DC. Prod. I0:399. I846] of Brazil, which differs in being puberulent, and in having shorter pedicels and longer calyx. Naiadothrix myriophylloides (Benth.) Pennell, comb. nov. [Herpestis myriophylloides Benth. l. c., 398. I846], of Brazil, is the only other known species of the genus.

ENCOPELLA Pennell, nom. nov.

Encopa Griseb. Cat. P1. Cub. I84. I866. Not Encopea, Presl, Bot. Bemerk. 83. I844.

Type species: Encopa tenuifolia Griseb.

Encopella tenuifolia (Griseb.) Pennell, comb. nov.

Encopa tenuifolia Griseb. Cat. P1. Cub. I84. 1866.

Sandy shores of lagoons, Santa Clara, Pinar del Rio and Isle of Pines. Endemic.

\section{ANISANTHERINA Pennell, gen. nov.}

Stem erect, I-4 dm. tall, branching, hirsute-pubescent with reflexed-spreading dark-jointed hairs. Leaves opposite, sessile, linear, sparingly minutely lobed, scabro-pubescent above, 4-6.5 $\mathrm{cm}$. long. Pedicels 25-35 (-45) $\mathrm{mm}$. long, bibracteolate about the middle. Calyx of 5 united sepals, the lobes shorter than the tube. Corolla I2-I4 mm. long, pinkish (not seen fresh), the lobes much shorter than the tube, the two posterior united only at base; within glabrous proximally, but pubescent over the bases of the posterior lobes. Filaments 4, lanate distally, the posterior pair shorter; anther-sacs unequal, the outer one smaller, glabrous. Style glabrous. Stigma linear, consisting of two lines, one down each side of style-apex. Capsule 7-8 $\mathrm{mm}$. long, globose with a mucro, glabrous, loculicidal and septicidal. Seeds $0.6-0.8 \mathrm{~mm}$. long, oblong-linear, reticulate, dark-brown, wingless. [Name from avıoos, unequal, and $\alpha \nu \theta \eta \rho$, anther.]

This monotypic genus resembles Agalinis, which however has both anther-sacs alike, pedicels not bracteolate, and seeds wider.

Anisantherina hispidula (Mart.) Pennell, comb. nov.

Gerardia hispidula Mart. Nov. Gen. et Sp. 3: I3. I829.

Moist savannas and borders of lagoons in pineland, Santa Clara, Pinar del Rio, Isle of Pines; Panama; Brazil. 


\section{Family BIGNONIACEAE}

Tabebuia camagueyensis Britton \& Wilson, sp. nov.

A shrub or a small tree up to $7 \mathrm{~m}$. high, the twigs lepidote. Petioles I-2.5 cm. long; leaves 5-I-foliolate, glabrous; leaflets chartaceous, elliptic to oblong or obovate, more or less lepidote, 4-6 $\mathrm{cm}$. long, rounded or emarginate at the apex, mostly narrowed at the base, dark green and dull above, pale green beneath; flowers few together on rather stout pedicels $1.5-2.5 \mathrm{~cm}$. long; bractlets subulate, $4 \mathrm{~mm}$. long; calyx narrowly campanulate, about I $5 \mathrm{~mm}$. long, obliquely toothed; corolla light pink to rose, campanulate, about $6 \mathrm{~cm}$. long; capsule linear, slightly curved, short-beaked, 9-1 $5 \mathrm{~cm}$. long, about $6 \mathrm{~mm}$. thick.

Savannas near Camaguey (Britton \& Cowell I3IIO).

Tabebuia savannarum Britton, sp. nov.

A small tree, about $4 \mathrm{~m}$. high, the twigs clothed, below the leaves, with linear, lepidote scales $4-5 \mathrm{~mm}$. long. Leaves simple, oblong-obovate, entire, I.5-3 cm. long, chartaceous or subcoriaceous, shining with impressed midvein above, dull, with prominent midvein and finely reticulated beneath, the petioles $4-5 \mathrm{~mm}$. long; flowers few, on pedicels about $5 \mathrm{~mm}$. long; calyx narrowly campanulate, 8-10 $\mathrm{mm}$. long, 2-lobed, the lobes acute; corolla pink, about $4 \mathrm{~mm}$. long.

Savannas near Camaguey (Britton \& Cowell I3202).

Tabebuia Cowellii Britton, sp. nov.

A tree 7-IO $\mathrm{m}$. high, the twigs stout, short, bearing several or numerous thick ovate to lanceolate scales I-2 mm. long below the leaves. Leaves oblanceolate to oblong-oblanceolate or some of them obovate, coriaceous, I.5-5 cm. long, finely lepidote, inconspicuously finely reticulate-veined beneath, retuse or rounded at the apex, cuneate at the base, the midvein prominent beneath, the petiole $3 \mathrm{~mm}$. long or less; flowers few together or solitary; pedicels 3-5 mm. long; calyx narrowly campanulate, 5-6 mm. long, loosely lepidote, unequally 5 -toothed, the teeth ovate; corolla pink, 4-5 cm. long; capsule linear, straight, IO-I $3 \mathrm{~cm}$. long.

Hillsides and plains, southern Oriente, along the coast. Type from Conde Beach, Guantanamo Bay (Britton 2I32).

COTEMA Britton \& Wilson, gen. nov.

Trees, with I-5-foliolate slender-petioled leaves, and rather large, long-pedicelled lateral or axillary flowers, solitary or few 
together. Calyx cylindric-campanulate, irregularly 2-4-toothed. Corolla oblique, funnelform-campanulate, unequally 5-lobed, vertically flattened, its lobes reflexed. Fertile stamens 4, didymamous, exserted; filaments slender; anther-sacs reflexed; sterile filament slender. Capsule terete, elongated, curved or coiled. Seeds oblong, thin, winged at each end. [Name an anagram of Tecoma.]

About 4 species, natives of eastern Cuba.

Type species: Tecoma spiralis $\mathrm{C}$. Wright.

Cotema spiralis (C. Wright) Britton \& Wilson, comb. nov.

Tecoma spiralis C. Wright; Griseb. Cat. P1. Cub. I94. I866. Eastern Cuba (C. Wright 3038).

Cotema woodfredensis Britton, sp. nov.

A tree up to 6 or $7 \mathrm{~m}$. high. Leaves $3-5$-foliolate; petioles slender, $2.5-5 \mathrm{~cm}$. long; petiolules slender, $8-25 \mathrm{~mm}$. long; leaflets subcoriaceous, obovate, the larger ones $5-7 \mathrm{~cm}$. long, $2-5 \mathrm{~cm}$. wide, all crenate above the middle, rounded or obtuse at the apex, narrowed or cuneate at the base, finely reticulate-veined and lepidote-punctate on both sides, shining above, rather dull beneath, turning dark in drying; capsule curved, greatly elongated, about $4 \mathrm{dm}$. long, beaked.

Rocky hillside, Sierra Nipe, between Piedra Gorda and Woodfred, Oriente (Shafer 3320).

Cotema apiculata Britton, sp. nov.

A tree about $5 \mathrm{~m}$. high. Leaves 5 -foliolate; petioles rather stout, 4-6 cm. long; leaflets coriaceous, dark green, elliptic to elliptic-obovate, 6-9 cm. long, 3-5 cm. wide, crenate, rounded and apiculate at the apex, obtuse or rounded at the base, strongly reticulate-veined and loosely lepidote-punctate on both sides, the petiolules $2-3 \mathrm{~cm}$. long; peduncles lateral, solitary or 2 together, stout, $3-5 \mathrm{~cm}$. long; calyx deciduous; capsule about $3 \mathrm{dm}$. long, 5-6 mm. thick, coiled or curved.

Edge of pineland thickets, between Rio Yamaniguey and Camp Toa, Oriente, at 400 meters altitude (Shafer 4I79).

A barren specimen from Pinar de El Purio, Cabonico, Oriente (Roig I34), is referred to this species with hesitation.

Cotema holguinensis Britton, sp. nov.

A tree up to $8 \mathrm{~m}$. high. Leaves $3-5$-foliolate; petioles slender, I-5 cm. long; petiolules slender, $2 \mathrm{~cm}$. long or less; leaflets 
firm-chartaceous, lepidote, elliptic to obovate, $2.5-6 \mathrm{~cm}$. long, 3.5 $\mathrm{cm}$. wide or less, crenate near the apex, or entire, obtuse or rounded at the apex, obtuse or subcordate at the base, reticulateveined above and faintly so beneath, the primary venation rather prominent on both sides; flowers 2 or 3 together in lateral clusters; pedicels slender, $3-4 \mathrm{~cm}$. long; flower-buds apiculate; calyx I.5 cm. long; "corolla yellow"; capsule curved, elongated, about $2.5 \mathrm{dm}$. long.

Vicinity of Holguin, Oriente. Type collected between Holguin and Cacocum (Shafer 1550).

\section{Family GESNERIACEAE}

Gesneria yamuriensis Britton \& Wilson, sp. nov.

A slow shrub. Leaves clustered near the apex of the stem, membranous, oblanceolate, 7-I2 cm. long, $2.5-4.5 \mathrm{~cm}$. broad, acute to acuminate at the apex, cuneate at the base, sessile, rugose, the veins impressed above, prominent beneath; inflorescence corymbiform, the peduncles axillary, many-flowered; pedicels filiform, 3-4 cm. long, glabrous or slightly pubescent; calyx-lobes linear, I $\mathrm{cm}$. long, glabrous, the tube Io-ribbed, $4.5-5 \mathrm{~mm}$. long; corolla scarlet, tubular, 3.5-4 cm. long, glabrous.

Coastal cliffs, Oriente. Type from face of cliff near Rio Yamuri (Shafer 7786). Related to G. purpurascens Urban.

Gesneria nipensis Britton \& Wilson, sp. nov.

An erect shrub, 3-I2 dm. high, the twigs, petioles and peduncles scabrous. Leaves coriaceous, oblanceolate, 6-I I cm. long, I..$-2.7 \mathrm{~cm}$. broad, acute to short-acuminate at the apex, cuneate at the base, dull and scabrous above, rufescent beneath, especially when young, faintly few-veined with the midvein impressed above and prominent beneath, the margin revolute, entire or slightly crenulate; petioles $1.5-1.7 \mathrm{~cm}$. long; peduncles axillary, 6-8 cm. long, 2-3-flowered; calyx-lobes lanceolate, $3 \mathrm{~mm}$. long; corolla tubular, yellow, I.5 cm. long, verrucose; capsule narrowly obovoid, ecostate, $8-9 \mathrm{~mm}$. long, $5 \mathrm{~mm}$. broad, finely verrucose.

Wet shady woods. Type from Sierra Nipe, near Woodfred, Oriente (Shafer 320I).

Gesneria clarensis Britton \& Wilson, sp. nov.

A tall shrub with slender grayish-brown branches, the twigs and petioles minutely scabrous. Leaves subcoriaceous, obovate, 7-IO $\mathrm{cm}$. long, $3-4.4 \mathrm{~cm}$. broad, rounded or acutish at the apex, 
broadly cuneate at the base, glabrous above, rufescent and minutely papillose beneath, the margin entire or serrulate; petioles I-I.5 cm. long; peduncles axillary, I-flowered, together with the angled pedicel, I-2 cm. long; calyx-lobes linear, 7-8 $\mathrm{mm}$. long; capsule obpyramidal, $5 \mathrm{~mm}$. long, prominently 5-ribbed.

Mountains of Santa Clara. Type from Sierra del Caballete, Sancti Spiritus mountains (Léon \& Clement 6504).

\section{Family LENTIBULARIACEAE}

Pinguicula lignicola Barnhart, sp. nov.

An epiphyte, growing on twigs of trees and shrubs. Leaves numerous in a dense rosette, sessile, linear-spatulate, entire, about I cm. long, minutely glandular-hairy but otherwise glabrous, withering-persistent; scapes solitary or few, filiform, weak, 2-4 cm. long; calyx about $2 \mathrm{~mm}$. long, the lobes obtuse, united to above the middle, the two lowest almost to the apex; corolla I-I.3 cm. long, white, the lobes subequal, about as long as the tube, obtuse, overlapping, the spur at a right angle with the tube, less than $2 \mathrm{~mm}$. long, saccate, obtuse; capsule not seen.

Oriente: Vicinity of Camp San Benito, February 24, I9Io (Shafer 403I, type); Camp La Gloria, December 24-30, I9Io (Shafer 8065) ; "La Yberia," a mining claim west of Baracoa, September 8, 1909 (Charles T. Ramsden).

Pinguicula benedicta Barnhart, sp. nov.

Leaves few or numerous in a dense rosette, sessile or nearly so, obovate to nearly orbicular, flat, entire, obtuse, $\mathrm{I}-2 \mathrm{~cm}$. long, minutely glandular-hairy above, glabrous beneath; scapes usually solitary, filiform, weak, $7-8 \mathrm{~cm}$. long; calyx about $3 \mathrm{~mm}$. long, strongly 2-lipped, the lips nearly distinct, the 3 lobes of the upper lip united to about the middle, the 2 lobes of the lower lip almost to the apex, all obtuse ; corolla $2-2.5 \mathrm{~cm}$. long, dark blue, distinctly 2-lipped, the 2-lobed upper lip much shorter than the 3 -lobed lower one, the 5 lobes all oblong, entire, overlapping, the spur continuous with the tube, $0.5-0.75 \mathrm{~cm}$. long, cylindric, obtuse; capsule not seen.

Oriente: Trail, Camp La Barga to Camp San Benito, February 22-26, I910 (Shafer 4025, type); "La Yberia," a mining claim west of Baracoa, September 8, 1909 (Charles T.Ramsden). 
Utricularia mixta Barnhart, sp. nov.

Stems slender, horizontal, submersed, free-floating except at the single point of attachment, up to $\mathrm{I} \mathrm{m}$. long, the older internodes 5-IO $\mathrm{cm}$. long; leaves alternate, but forked from the very base and thus appearing opposite, each fork pinnately decompound with filiform segments, Io-20 $\mathrm{cm}$. long, one fork usually much more copiously bladder-bearing than the other; mature bladders I-I.5 mm. in diameter; scapes solitary, borne at alternating nodes, erect, 8-25 cm. long, very slender, less than $2 \mathrm{~mm}$. thick, 6-I2-flowered; scales none, or sometimes I or 2, like empty bracts, near the base of the raceme; bracts ovate, acute, 2-3 $\mathrm{mm}$. long, concave and often sheathing the pedicels; pedicels 3-8 $\mathrm{mm}$. long, at first erect but strongly recurved at maturity; calyx-lobes subequal, ovate, obtuse or acute, or the lower emarginate, about $2 \mathrm{~mm}$. long, slightly accrescent and spreading under the mature fruit; corolla yellow, the upper lip subtriangular, emarginate, about $3 \mathrm{~mm}$. long and broad, the lower lip rounded, truncate or slightly emarginate, broader than long, 5-7 $\mathrm{mm}$. long, IO-I $2 \mathrm{~mm}$. broad, the palate prominent, faintly 2 -lobed, the spur conic-subulate, porrect, slightly shorter than the lower lip; ovules numerous; capsule spheric, $2-4 \mathrm{~mm}$. in diameter, apiculate by the remains of the stigma; seeds by abortion few, 7-Io, flat, peltate, winged all around, large for the genus, the body lenticular, about $2 \mathrm{~mm}$. in diameter, the wing up to $0.5 \mathrm{~mm}$. wide.

Type collected on muddy borders of a lagoon, Vivijagua, Isle of Pines, February 28-29, I9I6 (Britton, Britton \& Wilson I5OI4).

In quiet water, Santa Clara, Pinar del Rio and Isle of Pines; distributed by Wright as $U$. foliosa (2895) (true $U$. foliosa is Wright 2895a, distributed as $U$. foliosa oligosperma) ; Colombia ; Brazil.

\section{Family ACANTHACEAE}

Tubiflora Shaferi P. Wilson, sp. nov.

Leaves basal, oblanceolate, runcinate-dentate, $2.5-5 \mathrm{~cm}$. long, o.8-I.3 cm. wide, deep-green and more or less densely pilose, especially when young, short-petioled; scapes $3-6 \mathrm{~cm}$. long, slender, clothed with appressed, imbricated, acute, scale-like leaves 3 $\mathrm{mm}$. long; spikes I-2 cm. long, the bracts ovate, rigid, $3.5-4 \mathrm{~mm}$. long, I.8-2 $\mathrm{mm}$. broad, obtuse or acutish at the apex, not keeled on the back, ciliate, appressed-pilose above within.

Pinelands, Sierra Nipe, near Woodfred, Oriente (Shafer 3562). 


\section{Family RUBIACEAE}

Machaeonia minutifolia Britton \& Wilson, sp. nov.

A shrub about $2 \mathrm{~m}$. high, the twigs spiniform, slender, sparingly leafy, finely pubescent when young, soon becoming glabrous, the old branches stout, light gray. Leaves elliptic or suborbicular to elliptic-obovate, somewhat conduplicate, I-2 $\mathrm{mm}$. long, ciliate, rounded at the apex, very nearly sessile; flowers glabrous, sessile or very nearly so in the cymes; calyx-lobes rounded, about as long as the tube; corolla white, about I.5 mm. long, its lobes obtuse; style about as long as the calyx-lobes; stigmas 2, short.

Palm barren, between Camaguey and Santayana (Britton 2397).

\section{Scolosanthus lucidus Britton, sp. nov.}

A shrub about I $\mathrm{m}$. high, with slender, terete, rough-puberulent, resinous branches. Leaves ovate-orbicular, coriaceous, 8-13 $\mathrm{mm}$. long, shining, nearly sessile, mucronate at the apex, rounded at the base, dark green with the midvein impressed above, dull green with midvein somewhat elevated beneath, the lateral venation wholly obscure, the margin revolute; calyx-lobes suborbicular, o. $8 \mathrm{~mm}$. broad, minutely hispidulous; corolla not seen; fruit (immature) subglobose, $4 \mathrm{~mm}$. in diameter, greenish.

Moa Bay, east of Rio Moa, Oriente (Shafer 8355, type) ; collected in the same region by Roig (60), and also collected in Cuba by Wright and mixed with Scolosanthus Wrightianus (2660 in part).

\section{Psychotria Clementis Britton, sp. nov.}

A shrub about $2 \mathrm{~m}$. high, glabrous throughout. Leaves membranous, narrowly obovate or oblanceolate, $8-16 \mathrm{~cm}$. long, rather strongly veined with the veins spreading-ascending, acuminate at the apex, cuneate at the base, the slender petioles I $\mathrm{cm}$. long or less; stipules broadly lanceolate, acuminate, incised and ciliate, united below, about $8 \mathrm{~mm}$. long; fruiting panicle corymbiform, about $7 \mathrm{~cm}$. broad; fruiting pedicels $5 \mathrm{~mm}$. long or less; fruit oblong, $7 \mathrm{~mm}$. long, about $5 \mathrm{~mm}$. thick, grooved, capped by the short calyx-limb.

Sierra del Caballete, Sancti Spiritus mountains, Santa Clara (Léon \& Clement 6522).

Psychotria bermejalensis Britton, sp. nov.

A shrub about $2 \mathrm{~m}$. high, the slender branches glabrous. Leaves elliptic, glabrous, rather thin, 5 -10 cm. long, the veins dis- 
tant, impressed above, prominent beneath, the apex acute or short-acuminate, the base narrowed or obtuse, the rather stout puberulent petioles $8-\mathrm{I} 5 \mathrm{~mm}$. long; stipules ovate, about $5 \mathrm{~mm}$. long; panicles terminal, peduncled, $4-5 \mathrm{~cm}$. long in fruit, glabrous; fruiting pedicels $2-5 \mathrm{~mm}$. long; fruit globose, small, about $3 \mathrm{~mm}$. in diameter, rather deeply grooved, red.

Between Yamuri Arriba and Bermejal, Oriente (Shafer 8442).

\section{Psychotria moensis Britton \& Wilson, sp. nov.}

A straggling shrub, the twigs terete, puberulent when young, flexuous, rather stout, the internodes short. Leaves clustered near the ends of the twigs, subcoriaceous, oblanceolate, glabrous, 2-4 cm. long, I.5 cm. wide or less, rounded or obtuse at the apex, cuneate at the base, rather strongly pinnately few-veined and with the midvein prominent beneath, very inconspicuously veined with the midvein impressed above, the stout petioles I-2 $\mathrm{mm}$. long; stipules distinct, about $4 \mathrm{~mm}$. long, deciduous; inflorescence terminal, few-flowered; peduncle rather stout, $\mathrm{I}-2 \mathrm{~cm}$. long; fruiting pedicels about $5 \mathrm{~mm}$. long; bractlets minute; fruit (immature) subglobose, a little longer than thick, about $5 \mathrm{~mm}$. in diameter, the persistent calyx-tube about $0.5 \mathrm{~mm}$. long.

Camp La Gloria, south of Sierra Moa, Oriente (Shafer 8273).

Psychotria toensis Britton \& Wilson, sp. nov.

A shrub 3-9 dm. high, the slender brown twigs puberulent when young. Leaves lanceolate to elliptic-lanceolate, $2-5.5 \mathrm{~cm}$. long, $0.7-2 \mathrm{~cm}$. wide, acute to acuminate at the apex, cuneate at the base, glabrous above, the midvein slightly elevated, the lateral veins prominent; free tips of the stipules oblong, $2-2.5 \mathrm{~mm}$. long, acute; inflorescence terminal, the peduncle $1.5-3 \mathrm{~cm}$. long, puberulent; corymbs trichotomous, I-I.5 cm. long, ebracteate; prophyllae oblong-lanceolate, $3 \mathrm{~mm}$. long, I mm. wide, puberulent; flowers sessile; calyx-tube puberulent, the lobes triangular or triangular-ovate; corolla $\mathrm{I} 2-\mathrm{I} 3 \mathrm{~mm}$. long, the lobes oblong to oblong-lanceolate, acute; fruit $4 \mathrm{~mm}$. broad, contracted at the commissure.

Moist rocky places along trail, Rio Yamaniguey to Camp Toa, Oriente (Shafer 4009).

Mitracarpum Fortunii Britton \& Wilson, sp. nov.

Annual. Stems branched at the base, the branches slender, erect, 6-9 cm. long, puberulent with incurved hairs. Leaves ob- 
long, 6-1o $\mathrm{mm}$. long, $2-3.5 \mathrm{~mm}$. broad, acute at the apex, smooth or nearly so, obscurely nerved, sessile, the margin more or less revolute; corolla white, the tube about I $\mathrm{mm}$. long, the lobes elliptic-ovate, about as long as the tube; capsule circumscissile.

Loma de Motembo, Santa Clara (Léon, Edmund \& Fortun 860I).

\section{Family CARDUACEAE}

Aster Leonis Britton, sp. nov.

Branched, $3 \mathrm{dm}$. high, the branches slender, densely shortpubescent. Leaves finely pubescent and scabrous, those of the branches linear or linear-oblong, entire, acute or acuminate, sessile, $2-5 \mathrm{~cm}$. long, those of the branchlets similar, much smaller; heads mostly solitary at the ends of the branchlets; involucre subhemispheric, 4-5 mm. high, its bracts linear-spatulate, ciliate, their green tips acutish; rays pink, about $1.5 \mathrm{~cm}$. long.

Marshes, west of Batabano, Havana (Léon \& Cazanas 5753).

Gundlachia apiculata Britton \& Blake, sp. nov.

Shrub I meter high, resinous, the stout angulate stem branched above, tuberculate-strigillose, the branches erect. Leaves oblongoblanceolate, $2.2-3.2 \mathrm{~cm}$. long, 5-7 mm. wide, apiculate at the rounded apex, cuneate at base, alternate, sessile, coriaceous, entire, triplinerved and somewhat reticulate, punctate, more or less vernicose-resinous; heads about 4 in a terminal cluster, equaled by the leaves; disk turbinate, $5-6 \mathrm{~mm}$. high, $3.5 \mathrm{~mm}$. wide; involucre about 4-seriate, graduated, 4-5 $\mathrm{mm}$. high, the phyllaries ovate-oblong, acute, appressed, indurated, scarious-margined, with darker subherbaceous glandular and glandular-ciliolate tips; rays about 2, white, oval, about $2 \mathrm{~mm}$. long; disk-corollas about 4, sparsely pilose toward tip of tube, $4.8 \mathrm{~mm}$. long, the tube $1.6 \mathrm{~mm}$., the teeth $2 \mathrm{~mm}$. long; achenes (immature) hispidulous, $1.5 \mathrm{~mm}$. long; pappus dull white, $4 \mathrm{~mm}$. long, the outer bristels shorter.

Camp La Gloria, south of Sierra Moa, Oriente (Shafer 8053).

Distinguished by its few heads and elliptic-obovate triplinerved leaves.

Gundlachia foliosa Britton \& Blake, sp. nov.

Shrub, 0.3 to I.3 meters high, somewhat glutinous, the stout erect striate branches tuberculate-strigillose, densely leafy, simple, or branched only in the inflorescence. Leaves obovate, I.2-I.8 $\mathrm{cm}$. long, 6-10 $\mathrm{mm}$. wide, usually apiculate at the rounded apex, rounded at base, alternate, erect, uniform, sessile, coriaceous, tri- 
plinerved, punctate, dull green both sides, glabrous; heads in dense terminal panicles of about 8 or Io, equaling or slightly exceeding the leaves; pedicels sparsely hispidulous, I-2 mm. long; heads $6 \mathrm{~mm}$. wide; disk turbinate, $6 \mathrm{~mm}$. high, $3.5 \mathrm{~mm}$. wide; involucre about 5 -seriate, graduated, $5 \mathrm{~mm}$. high, the phyllaries lance-ovate (outer) to oblong, acute to acuminate, appressed, indurated and scarious-margined with dark subherbaceous tips, sparsely glandular-hispidulous at apex; rays 2 , white, oval, tridenticulate, $3.2 \mathrm{~mm}$. long; disk-corollas 3 , hispid-pilose at base of throat, $4.5-4.8 \mathrm{~mm}$. long, the slender tube $\mathrm{I} .5 \mathrm{~mm}$., the lanceolate recurved teeth $2-2.5 \mathrm{~mm}$. long; achenes oblong-cylindric, 5-angled, hispidulous, $2 \mathrm{~mm}$. long; pappus dull white, $4 \mathrm{~mm}$. long, the outer bristles shorter.

On dryish rocks, Camp La Gloria, across Sierra Moa, to Moa Bay, Oriente (Shafer 8280).

Readily recognized by its small crowded obovate leaves.

Gundlachia cubana Britton \& Blake, sp. nov.

Low shrub, growing in clumps, branched, more or less resinous, the stem stoutish, densely tuberculate on the angles, densely leafy. Leaves narrowly oblanceolate, I.7-2.7 cm. long, 2.5-4 $\mathrm{mm}$. wide, acute, narrowed to the sessile base, alternate, coriaceous, entire, I-nerved, punctate, glabrous, dull green; panicles terminal, sessile, about 8-headed, equaled or slightly exceeded by the leaves; pedicels I to $8 \mathrm{~mm}$. long; heads turbinate, about 7 $\mathrm{mm}$. wide; disk $6 \mathrm{~mm}$. high, 4-5 $\mathrm{mm}$. wide; involucre about 4-seriate, graduated, $4.5 \mathrm{~mm}$. high, the phyllaries lance-ovate, acuminate, indurated, scarious-margined, the subherbaceous glandular-hispidulous and ciliolate tips somewhat recurved in age; rays 4, white, oval, $4 \mathrm{~mm}$. long; disk-corollas 5, sparsely pilose at base of throat, $4.5 \mathrm{~mm}$. long, the tube I. $5 \mathrm{~mm}$., the teeth $2.2 \mathrm{~mm}$. ; achenes obovoid, densely hispid-pilose, I-I.4 mm. long; pappus dull white, $4 \mathrm{~mm}$. long, the outer bristles shorter.

Northern Oriente. Type collected by water near mangroves, mouth of Rio Yamaniguey (Shafer 4255).

Erigeron Taylori Britton \& Wilson, sp. nov.

Diminutive, glabrous. Scapes filiform, prostrate or spreading, only $3 \mathrm{~cm}$. long or less, monocephalous, bearing several oblong or oblanceolate scales about I mm. long; basal leaves tufted, spatulate, entire, obtuse or rounded, the blade $2-4 \mathrm{~mm}$. broad, the slender petiole $15 \mathrm{~mm}$. long or less; involucre $2 \mathrm{~mm}$. long, its linear-lanceolate, acute or acuminate bracts reflexed in age and 
persistent; receptacle foveolate; rays white; ligule linear, ı.6-1.8 $\mathrm{mm}$. long; achenes ellipsoid-cuneiform, $0.5 \mathrm{~mm}$. long, hirsute with short hairs; pappus about twice as long as the achene.

Upper Guama River, Sevilla Estate, near Santiago, Oriente (Taylor $I 8 I$ ), forming moss-like patches.

Erigeron Earlei Britton \& Wilson, sp. nov.

Loosely hirsute; stems solitary or few together, slender, erect, about $2.5 \mathrm{dm}$. high, few-branched above. Leaves membranous, the basal and lower ones spatulate or oblanceolate, $3-4.5 \mathrm{~cm}$. long, obtuse or rounded at the apex, coarsely crenate, narrowed into margined petioles or sessile, or the lowest with slender petioles $\mathrm{I}-2 \mathrm{~cm}$. long, the uppermost oblong, acute, entire, $\mathrm{I}-2 \mathrm{~cm}$. long, sessile; heads several, slender-peduncled, the peduncles bearing I-3 linear or lanceolate bracts I-4 $\mathrm{mm}$. long; involucre subhemispheric, $4 \mathrm{~mm}$. high, its bracts in about 2 series, linearlanceolate, acuminate, the outer ones pilose, somewhat shorter than the inner, all reflexed in age and persistent; rays white; ligule linear, I.5-1.7 mm. long; achenes oblong-ellipsoid, $0.6 \mathrm{~mm}$. long, hirsute; pappus 2-3 times as long as the achene.

Rocky river-bed, Hanabanilla Falls, Trinidad Mountains, Santa Clara (Britton, Earle \& Wilson 4843).

Borrichia cubana Britton \& Blake, sp. nov.

Shrub, oppositely branched, the stem and branches sparsely appressed-pilose, glabrate. Leaves opposite, the blades oblanceolate to spatulate-obovate, $3-3.8 \mathrm{~cm}$. long, 5-I I mm. wide, mucronate-apiculate at the rounded apex, cuneately narrowed into the petiole, entire or sparsely spinulose-toothed below, coriaceous, obscurely triplinerved, canescent-lanate both sides; petioles narrowly margined, broadened and connate at base, 6-10 mm. long; peduncles terminal, rather sparsely appressed-pilose, thickened above, 5-7 cm. long; heads $2.2 \mathrm{~cm}$. wide; disk subglobose, I-I.2 $\mathrm{cm}$. thick; involucre about 4-seriate, graduated, 8-9 mm. high, the outer phyllaries deltoid-ovate, acute and weakly mucronulate, with indurated base and spreading canescent-lanate apex, the inner broader, ciliate, otherwise subglabrous, with cuspidatemucronate spreading tips about $2 \mathrm{~mm}$. long; rays about I5, yellow, oval, $6 \mathrm{~mm}$. long; disk-corollas yellow, slender, glabrous, 5.8 $\mathrm{mm}$. long; pales similar to the outer phyllaries, broad, indurated, ribbed, with erect stiffly mucronulate tips about I mm. long; achenes quadrangular, black, glabrous, $3 \mathrm{~mm}$. long; pappus a thickened angulate crown $0.8 \mathrm{~mm}$. long. 
Swamp near Atares Castle, Havana, June, I9I7 (Léon 7244).

Nearest $B$. frutescens (L.) DC., but easily distinguished by its merely short-cuspidate outer phyllaries and pales.

Spilanthes montana Britton \& Blake, sp. nov.

Shrub about $5 \mathrm{dm}$. high, sparsely dichotomously branched, the stem stout, angulate, densely leafy, the branches erect, the internodes mostly 4-10 $\mathrm{mm}$. long. Leaves opposite, the blades lanceolate, $2.5-4 \mathrm{~cm}$. long, $4-8 \mathrm{~mm}$. wide, narrowed to an obtuse apex, cuneate at base, entire, coriaceous, slightly revolute, triplinerved, glabrous, shining above, duller beneath; petioles scarcely margined, $2-5 \mathrm{~mm}$. long ; peduncles terminal and axillary, monocephalous, glabrous, striate, $16-34 \mathrm{~cm}$. long, sometimes bearing two spatulate denticulate bracts $4 \mathrm{~mm}$. long below the head; heads discoid, subglobose to ovoid-subglobose, rounded, 6-10 $\mathrm{mm}$. high, 9-10 $\mathrm{mm}$. thick ; involucre 3 -seriate, slightly graduated, 5-6 mm. high, the phyllaries oblong or oval-oblong, rounded, denticulate-erose above, sparsely glandular-ciliolate below, thickherbaceous with subscarious margin, papillose on back, obscurely nerved; disk-corollas white, $3.2 \mathrm{~mm}$. long, sparsely papilloseglandular below, with short obscure tube; pales blunt, erosedenticulate above, papillose-glandular on keel throughout and sparsely hispid-pilose below; achenes (not quite mature) oblongobovate, $3 \mathrm{~mm}$. long, ciliate; awns 2 , unequal, ciliate, $2-2.8 \mathrm{~mm}$. long.

Top of Cajalbana, near the fall of the arroyo, Pinar del Rio, Cuba, April 6, I915 (Léon \& Charles 4936).

Related to S. insipida Jacq. and S. pauciceps (Griseb.) Blake, but readily distinguished by its densely leafy stems and lanceolate entire leaves.

Chaptalia comptonioides Britton \& Wilson, sp. nov.

Leaves several or numerous, deeply pinnatifid, spatulateoblanceolate in outline, 3-15 cm. long, short-petioled, obtuse or acutish, membranous, the upper surface dark green, glabrous or somewhat floccose, the under surface densely white-lanate, the ovate terminal lobe larger than the semicircular lateral ones; scape slender, floccose at least above, $2 \mathrm{dm}$. high or less; involucre subhemispheric, 9-I I mm. high, its linear bracts acute or acuminate, white-tomentulose with a green midvein; achene fusiform, minutely hispidulous, brown, the angles white, the filiform beak about as long as the body; pappus longer than the beak, pale brownish-white. 
River-cliffs, Enseneda de Mora, Oriente (Britton, Cowell \& Shafer I2937).

Chaptalia Shaferi Britton \& Wilson, sp. nov.

Leaves $3-8 \mathrm{~cm}$. long, lyrate or lyrate-pinnatified, short-petioled or sessile, obtuse or acutish, the terminal lobe much larger than the others, the upper surface dark green, glabrous, the under surface densely white-lanate; scape very slender, glabrous below, slightly tomentose above, $2 \mathrm{dm}$, long or less; involucre subcampanulate, about $5 \mathrm{~mm}$. high, its bracts linear, acute, glabrous; achenes fusiform, minutely hispidulous, brown, the slender beak about half as long as the body; pappus longer than the achene, brownish-white.

River-banks and wet rocks, Oriente. Type from sandy bank of Rio Yamaniguey (Shafer 4203). Confused in C. Wright's collection with $C$. stenocephala Griseb., and with C. pumila of Jamaica.

Chaptalia Rocana Britton \& Wilson, sp. nov.

Leaves several, membranous, spatulate-oblanceolate, $15 \mathrm{~cm}$. long or less, repand-pinnatifid, crenate, or some of the smaller ones entire, acute or obtuse, dark green and glabrous or nearly so above, white-lanulose beneath, the petioles sometimes as long as the blades; scapes nearly filiform, 5-10 cm. long, floccose or becoming glabrous; involucre subhemispheric, 6-7 $\mathrm{mm}$. long, its bracts linear, acuminate, glabrate; achenes (immature) filiform, minutely hispidulous, brown, the short beak less than one quarter the length of the body; pappus longer than the achene, brownishwhite.

Mountains of southern Santa Clara. Type from stones in Rio Caracusey, Banao Mountains (Léon \& Roca 7904). 





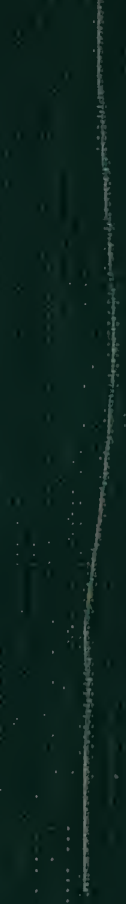

